\title{
Public Acceptance of Nature-Based Solutions for Natural Hazard Risk Reduction: Survey Findings From Three Study Sites in Europe
}

\author{
Carl C. Anderson ${ }^{1 *}$, Fabrice G. Renaud ${ }^{1}$, Stuart Hanscomb ${ }^{1}$, Karen E. Munro ${ }^{2}$, \\ Alejandro Gonzalez-Ollauri ${ }^{2}$, Craig S. Thomson ${ }^{2}$, Eija Pouta ${ }^{3}$, Katriina Soini ${ }^{3}$, \\ Michael Loupis ${ }^{4,5}$, Depy Panga ${ }^{4}$ and Maria Stefanopoulou ${ }^{4}$ \\ ${ }^{1}$ School of Interdisciplinary Studies, University of Glasgow, Dumfries, United Kingdom, ${ }^{2}$ The BEAM Research Centre, School of \\ Computing, Engineering and Built Environment, Glasgow Caledonian University, Glasgow, United Kingdom, ${ }^{3}$ Natural Resources \\ Institute Finland (Luke), Helsinki, Finland, ${ }^{4}$ Innovative Technologies Centre, Athens, Greece, ${ }^{5}$ General Department, National and \\ Kapodistrian University of Athens, Athens, Greece
}

OPEN ACCESS

Edited by:

Giuseppe Feola,

Utrecht University, Netherlands

Reviewed by:

Alexander Van Der Jagt, Wageningen University and Research,

Netherlands

Gerd Lupp,

Technical University of Munich,

Germany

*Correspondence:

Carl C. Anderson

c.anderson.4@research.gla.ac.uk

Specialty section:

This article was submitted to Interdisciplinary Climate Studies,

a section of the journal

Frontiers in Environmental Science

Received: 10 March 2021 Accepted: 12 July 2021 Published: 26 July 2021

Citation:

Anderson CC, Renaud FG, Hanscomb S, Munro KE, Gonzalez-Ollauri A, Thomson CS, Pouta E, Soini K, Loupis M, Panga $D$ and Stefanopoulou M (2021) Public

Acceptance of Nature-Based Solutions for Natural Hazard Risk Reduction: Survey Findings From

Three Study Sites in Europe.

Front. Environ. Sci. 9:678938 doi: 10.3389/fenvs.2021.678938
Climate change is one factor increasing the risk of hydro-meteorological hazards globally. The use of nature-based solutions (NbS), and more specifically ecosystem-based disaster risk reduction measures (Eco-DRR), has become a popular response for risk reduction that also provides highly-valued co-benefits. Public acceptance is of particular importance for $\mathrm{NbS}$ since they often rely on local collaborative implementation, management, and monitoring, as well as long-term protection against competing societal interests. Although public engagement is a common goal of NbS projects, it is rarely carried out with a sufficient understanding of the (de)motivating factors tied to public perceptions. Successful collaboration demands consideration of societal attitudes and values in relation to risk, nature, and place. However, existing research does not sufficiently explore these themes together, their interactions, and their implications for the public acceptance of $\mathrm{NbS}$. This may lead to misaligned public expectations and failed participatory initiatives, while jeopardizing the success of NbS projects and their continued funding and uptake. We conducted citizen surveys within local NbS "host" communities to determine the degree of pro-NbS attitudes and behavior, associated variables, and how these may be leveraged to increase acceptance. We compared results across sites, relying primarily on correlations and regression models along with survey comments and expert knowledge. Three distinct rural NbS being implemented within the OPERANDUM project aim to reduce risk from (socio-)natural hazards in Scotland (landslides and coastal erosion; $n=66$ respondents), Finland (eutrophication and algal blooms; $n=204$ ) and Greece (river flooding and water scarcity; $n=84$ ). Our research thus centers on rural NbS for risk reduction within a large EU project. Trust in implementers is a consistent factor for defining attitudes towards the NbS across the sites, and attitudes are strongly associated with respondents' commitment to nature and behavioral acceptance (i.e., willingness to engage). Behaviorial acceptance is most consistently predicted by connectedness to place and the extent of expected future impacts. Skepticism of NbS effectiveness leads to high public demand for relevant evidence. To increase public acceptance, we recommend greater framing of $\mathrm{NbS}$ in 
relation to place-based values as well as demonstration of the effectiveness of NbS for risk reduction. However, distinct hazard types, proposed NbS, and historical characteristics must be considered for developing strategies aimed at increasing acceptance. An understanding of these characteristics and their interactions leads to evidence-based recommendations for our study sites and for successful $\mathrm{NbS}$ deployment in Europe and beyond.

Keywords: nature-based solutions (nbs), climate change, public acceptance, public perception, stakeholder engagement, hydro-meteorological hazards, community action

\section{INTRODUCTION}

Public attitudes and behaviors are central to tackling the greatest social and environmental issues of our time (Reid et al., 2010; World Bank 2015). The importance of public attitudes and meaningful participation has long been recognized for environmental protection (Blake 1999; Reed 2008) and within the broader context of sustainable development (Chambers 1994). Over the past several decades, the field of disaster risk reduction has undergone a learning process and generally taken up these calls for increasing local and community involvement (Maskrey 1989; La Tozier de Poterie and Baudoin, 2015; Macherera and Chimbari 2016; Begg et al., 2018), spurred on by an understanding of interconnections among environmental protection, sustainable development, disaster risk, and climate change (Turner et al., 2003; Birkmann and Teichman 2010; United Nations 2015; United Nations Office for Disaster Risk Reduction 2015).

Phrases such as "integration of local stakeholder knowledge," "bottom-up approach," and any number of verbs following the prefix "co-," to describe public actions within risk management projects are commonplace. The ubiquity of this terminology is indicative of the shift towards increased reliance on public support (i.e., non-state actors and individuals) (Mees et al., 2012; Penning-Rowsell and Johnson 2015; Bubeck et al., 2017; Begg et al., 2018; Kuhlicke et al., 2020; Zingraff-Hamed et al., 2020; Puskás et al., 2021) that has also been codified in relevant policy such as the European Water Framework Directive (European Commission 2000). Indeed, this shift has been most prominently manifested in the context of flood risk management in Europe (Begg et al., 2011; Begg et al., 2018; Bark et al., 2021) and promoted as a departure from a "decide, announce, defend" practitioner-public interaction model to an "engage, deliberate, decide" approach (Daly et al., 2015). An increasing reliance on the public for addressing environmental risk has been attributed to, among other reasons, a decline in trust in policy-makers (van der Vegt 2018), a push for increased legitimacy and democratic decision-making, a recognition of improved outcomes (Begg et al., 2018; Zingraff-Hamed et al., 2020), the ability to break gridlock and prevent litigation (Irvin and Stansbury 2004), and the extra burden on disaster risk managers due to climate change and land-use conflict (Wamsler et al., 2019).

However, public acceptance and the expected resulting positive outcomes are uncertain and highly predicated on context (Godschalk et al., 2003; Irvin and Stansbury 2004; Euler and Heldt 2018; Wamsler et al., 2019). Additionally, the success of scientific innovations for sustainable development is often determined by public perceptions rather than scientific consensus (Hopkins et al., 2012). Nature-based solutions (NbS) that aim to reduce risk from natural hazards while also providing a wide range of ecosystem services, or benefits, to people (CohenShacham et al., 2016) can be considered one such innovation. $\mathrm{NbS}$ encompass measures for ecosystem-based disaster risk reduction (Eco-DRR) and ecosystem-based adaptation to climate change (EbA) (Cohen-Shacham et al., 2016). We focus on Eco-DRR NbS in this study. The substantial funding for $\mathrm{NbS}$ research and its ongoing implementation across Europe is indicative of the increasing political and scientific consensus for these measures (Faivre et al., 2017; Zingraff-Hamed et al., 2020; European Commission 2021).

A greater reliance on local stakeholders for cooperation with $\mathrm{NbS}$ during implementation, maintenance, management, and monitoring phases means public acceptance is crucial for their success (Ferreira et al., 2020; Anderson and Renaud 2021; Bark et al., 2021; Puskás et al., 2021). The multi-functionality of NbS entails greater opportunity for stakeholder participation but also greater risk of conflict (Naumann and Kaphengst 2015; Connop et al., 2016; European Commission 2021). Additionally, in the short-term NbS can be less effective than other measures and can require increased long-term protection (e.g., conservation) when faced with competing societal interests within their "host" communities (i.e., the groups of local citizen stakeholders living and interacting with $\mathrm{NbS}$ ) (Kabisch et al., 2016; Anderson and Renaud 2021). Negative public perceptions are commonly considered a potential barrier to NbS uptake (Connop et al., 2016; Heldt et al., 2016; Raymond et al., 2017; Han and Kuhlicke 2019) and the centrality of local stakeholder engagement is reflected in policy-oriented $\mathrm{NbS}$ guidelines (International Union for Conservation of Nature 2020).

Although public participation is a common goal of NbS projects and a prominent feature of relevant guidelines (International Union for Conservation of Nature 2020), it is rare that stakeholder engagement processes are based on a thorough understanding of the motivating and conflicting factors related to public perceptions (Zingraff-Hamed et al., 2020). Research for successful NbS has focused more on its physical implementation rather than local public attitudes and supportive behavior, although a recognition of the latter is increasing (Howgate and Kenyon 2009; Buchecker et al., 2013; 
Kabisch et al., 2016; Triyanti et al., 2017; Ferreira et al., 2020). There is also increasing attention on stakeholder preferences within NbS projects, although the focus of these studies generally involves the weighting of criteria for instrumental project outcomes (Giordano et al., 2020; Pugliese et al., 2020; Ruangpan et al., 2020), rather than a broader analysis of relevant perceptions and values. This lack of background social science research on $\mathrm{NbS}$ for risk reduction can lead to misaligned expectations (Verbrugge et al., 2017) and communities being blamed for the failure of participatory initiatives (Biswas et al., 2009; Barthélémy and Armani 2015). If facilitated without proper intentions and a rich contextual understanding, local participation may be viewed as performative rather than contributory and lead to both negative perceptions and unsatisfactory project outcomes (Irvin and Stansbury 2004; Begg et al., 2018; Euler and Heldt 2018; Wamsler et al., 2019). In contrast, effective risk or project-related communication and meaningful participation is more likely to be successful with an understanding of individuals' perspectives and values (Moser and Dilling 2011; Simon et al., 2013; Raymond et al., 2017; Brink and Wamsler 2019). Transparent participation and framing of communication can enhance identification of shared goals and improve engagement (Buijs 2009; Moser and Dilling 2011; Simon et al., 2013; Everett et al., 2018), even in contexts of inherently misaligned public-practitioner objectives (Pfadenhauer 2001; Williams et al., 2017).

Perspectives and values vary greatly both across and within the contexts of NbS sites and should be explored on a case-by-case basis but with systematic consideration of relevant variables. In their review of 99 articles related to public acceptance of NbS for disaster risk reduction, Anderson and Renaud (2021) identified the variables found to influence acceptance and their frequency in the literature. The variables were classified as being most relevant to the individual, the society, or the NbS measure itself, and the most frequently cited included perceived benefits and trade-offs, effectiveness of risk reduction, cost, risk perception, place attachment, and trust in the responsible party. Many of the variables can also be classified into the general themes of perceptions of risk, nature, and place, the relevance of which is also suggested by prior research. For example, perceived concern for hazards (Fordham et al., 1991; Ding et al., 2019) or their negative impacts (Böhm and Hans-Rüdiger, 2000; Bubeck et al., 2012; Schernewski et al., 2018; Sjoberg 1999, 2000) are widely cited as potential (context-dependent) motivators of (support for) protective action. Similarly, individuals' "acceptance" or intolerance of risk can determine whether they support risk reduction and its required personal or community resources (e.g., time or money) (Fischhoff et al., 1978; Baird 1986; Chowdhury 2003; Buchecker et al., 2016; Holstead et al., 2017).

Since both using natural elements and supporting ecosystems are central to $\mathrm{NbS}$, the long-standing and well-established research on determinants of pro-environmental attitudes and behaviors is also highly relevant (Liere et al., 1980; Stern 2000; Steg and Vlek 2009). Cleaner air (Groot and Groot 2009; Miller and Montalto 2019) and water (Schaich 2009; Koutrakis et al., 2011) and greater biodiversity (Howgate and Kenyon 2009;
Schaich 2009; Jones et al., 2012; Roca and Villares 2012; Scholte et al., 2016; Everett et al., 2018; Miller and Montalto 2019) and wildlife habitat (Kenyon 2007; Herringshaw et al., 2010; Evans et al., 2017; Beery 2018) can be crucial for public acceptance of $\mathrm{NbS}$. The perceived importance of positive environmental outcomes as motivators is related to individuals' sense of interdependence and commitment to nature (Davis et al., 2011).

Lastly, whether NbS are seen to enhance or degrade local history, identity, and place can influence the degree of public acceptance (Buijs 2009; Bihari and Ryan 2012; Roca and Villares 2012; Brink and Wamsler 2019). Individuals' connectedness to place may determine whether shifts away from the status quo or the idealized environment face opposition (Buijs 2009; Jacobs and Buijs 2011; Pueyo-Ros et al., 2019) or if NbS that enhance local values find support (Schmidt et al., 2014; Brink and Wamsler 2019). Recent literature reviews on the subject have also found risk, nature, and place to be key themes of variables that influence perceptions of NbS across diverse geographic and hazard contexts (Han and Kuhlicke 2019; Anderson and Renaud 2021).

These research streams from disaster risk reduction and risk perception, environmental attitudes and behavior, and attachment/connectedness to place provide fertile ground for explaining public acceptance of rural $\mathrm{NbS}$ (projects) for risk reduction. However, the associated variables from these fields have only very rarely been considered within the same studies on public acceptance (Buijs 2009). Our research addresses the resulting insufficient understanding of what determines public attitudes and behavior in this context.

The ongoing EU-funded OPERANDUM project $^{1}$ is implementing $\mathrm{NbS}$ in Europe to reduce risk from hydrometeorological hazards. We conducted surveys with residents of three rural OPERANDUM NbS host communities across Europe (Scotland, Finland and Greece). By 1) assessing public attitudinal and behavioral acceptance of $\mathrm{NbS}$ and 2) determining what variables define and are related to acceptance, we aim to address the outlined knowledge gaps and help ensure successful $\mathrm{NbS}$ within the study sites while also identifying more general lessons and recommendations for $\mathrm{NbS}$.

We define public acceptance broadly to encompass, for example, cooperation, engagement, satisfaction, and buy-in while avoiding conflict, opposition, and a lack of participation (Anderson and Renaud 2021). It thus describes both attitudes and behaviors toward $\mathrm{NbS}$ while recognizing their potentially distinct motivators. We use a comparative research approach to identify similarities and divergence across the sites (Przeworksi and Teune 1970; Lijphart 1975; Mills et al., 2006). Our research compares three rural sites that were all in the mature planning stage prior to deploying NbS for risk reduction. However, within the limits of the OPERANDUM project, our study site selection then seeks to maximize contextual differences across sites in terms of social and environmental systems. This research design can be described as the "most different system" approach (Przeworski and Teune 1970). Divergence in results across sites demands a systematic

${ }^{1}$ https://www.operandum-project.eu 


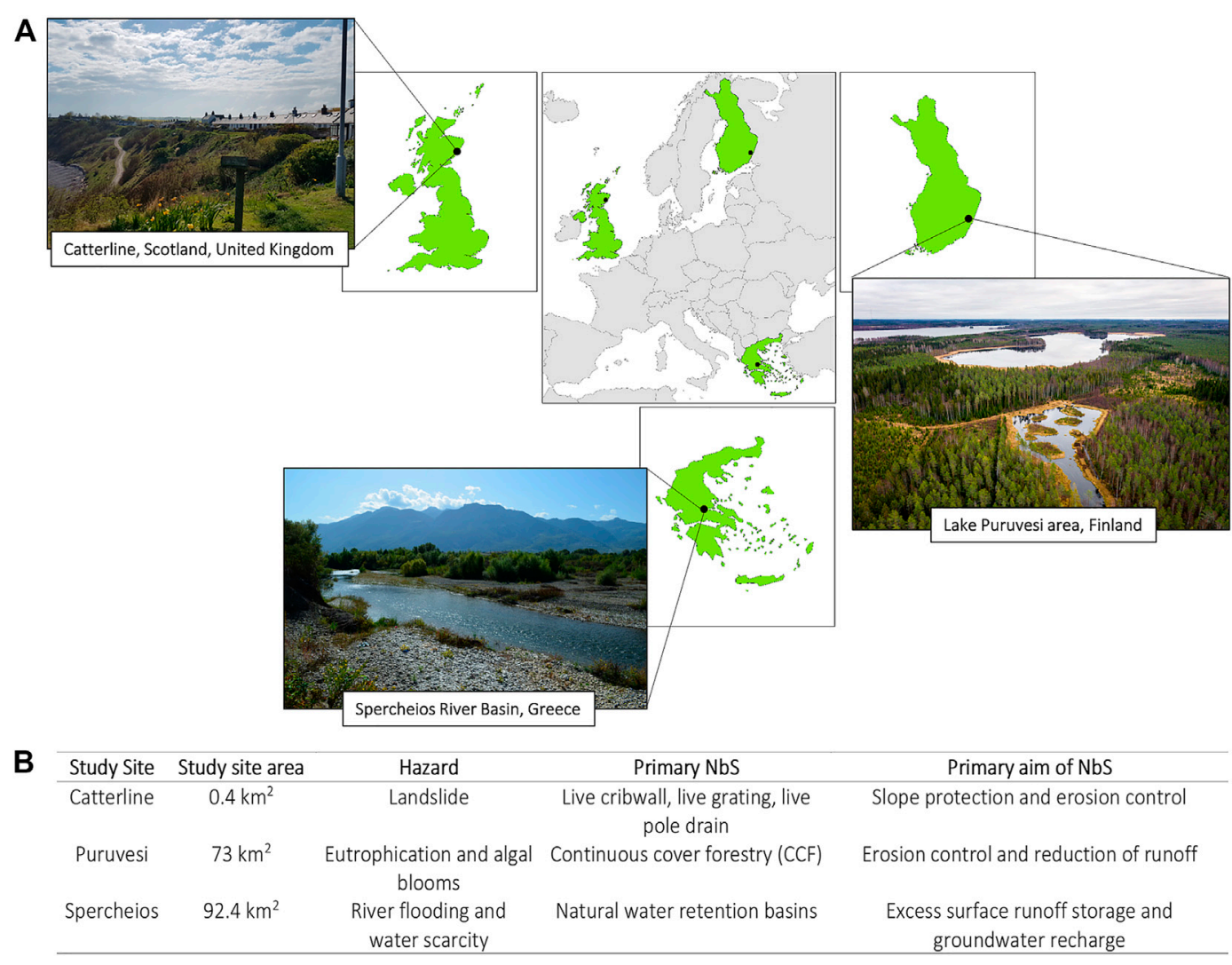

FIGURE 1 | Three European NbS study sites (A) and their characteristics, including hazard type and primary NbS being implemented within the OPERANDUM project (B). Map: European Commission, Eurostat, https://ec.europa.eu/eurostat/web/gisco/geodata/reference-data/administrative-units-statistical-units/countries. Photo credits: Catterline, Dr Karen Munro; Puruvesi, Pro Puruvesi ry; Spercheios, KKT-ITC S.A.

exploration of contextual characteristics, while similarities across sites leads to cautious inferences regarding generalizability of the independent variables in contexts of rural and externally initiated $\mathrm{NbS}$ projects for risk reduction. Based on the risk, nature, and place literature described above, we set out with the hypothesis that these variables will be influential for public acceptance of each NbS across the sites, testing this using maximally different contexts.

We are not aware of any similar studies that compare results across distinct rural study sites with different natural hazards, social and cultural characteristics, and proposed $\mathrm{NbS}$ with the primary objective of disaster risk reduction. We combined the comparative approach with psychometric methods since these are suitable for measuring individuals' perceptions through standardized survey items and composite scales (Borsboom 2005) for bivariate and multivariate statistical analyses.

We first provide a brief background on the study sites and detailed description of survey sampling, survey design, and data analysis. Next, results are structured based on the following research questions:

RQ1) What is the degree of public acceptance within the $\mathrm{NbS}$ sites and how does this differ across the sites?

RQ2) What variables define attitudinal acceptance, what is their strength within and across sites, and are perceptions of risk, nature and place associated with them?
RQ3) What variables define, correlate with, and explain behavioral acceptance (i.e., willingness to engage), and do attitudes towards NbS moderate their strength?

We then discuss key findings across the sites, their relation to prior research, and corresponding recommendations for increasing public acceptance of $\mathrm{NbS}$ within the sites and beyond. This is followed by a reflection on the study's limitations, the direction of further research needed, and a conclusion.

\section{STUDY SITES}

Our three European study sites are Catterline, Scotland, United Kingdom; the Lake Puruvesi area in Eastern Finland, and the Spercheios River Basin in Stereá Elláda, Central Greece (Figure 1). All three sites are rural and have relatively low-density populations living nearby who are exposed to hydrometeorological hazards. Additionally, the sites were all at similar points in their project timeline-the NbS had not yet been deployed by the project, but the stakeholder engagement process had begun and NbS planning was at a mature stage. Because contact had already been made with residents during limited prior outreach activities, there was a baseline level of 
awareness of the OPERANDUM NbS work among the respondents. These three sites were selected within the OPERANDUM project to cover a diverse set of social and environmental contexts, including spatial scales (Catterline is much smaller than the other sites), as well as diverse hazards and $\mathrm{NbS}$. In this way, the survey variables are tested for both their sitespecific and general relevance.

\section{Catterline, Scotland, United Kingdom}

Catterline is a small, rural, and scenic seaside village in Northeast Scotland with important historic and cultural relevance. The community has a long history of landslides, soil erosion, and related coastal hazards (Gonzalez-Ollauri and Mickovski 2017). Prolonged periods with heavy rainfall, surface water accumulation, fluctuations in groundwater, spring tides, storm surge, and high winds are all long-standing issues that contribute to landslides in Catterline. The last major landslide event, before the surveys were conducted in September 2019, occurred in October 2012.

Along with a detraction from the scenic beauty, the impacts of landslides in the community are most frequently road closures that can inhibit both the residents' recreational opportunities and access to essential services. There is also a fear of property damage or personal injury since past landslides have come within meters of residences.

Recent work to mitigate landslide risk has involved live ground anchor systems and live drainage systems making use of locally available willow branches, as well as the (re)planting of woody seedlings and cuttings along some sections of the slopes. These measures, including live cribwalls and grating, were being planned for deployment by the OPERANDUM project when the surveys were carried out. Additionally, a stabilization effort using geogrid mesh with vegetation was completed in August 2019 by members of a community group-the Catterline Braes Action Group $\left(\mathrm{CBAG}^{2}\right)$. The group was formed following landslides during the winter of 2012/2013. Most members live in the village and it is supported by voluntary resident engagement, with several highly engaged residents and many others supportive.

\section{Lake Puruvesi Area, Finland}

Lake Puruvesi and its surroundings in South-eastern Finland are rural, scenic, and culturally significant. Puruvesi is particularly wellknown for its water clarity. While most of the $416 \mathrm{~km}^{2}$ lake is in excellent ecological condition, the frequency of blue-green (cyanobacterial) algal blooms related to eutrophication has increased within portions of the lake, particularly in its northwestern extent near the Lake Kuona-Vehkajärvi sub-catchment area.

The dominant land-use in the Lake Puruvesi catchment is forestry ( $92 \%$ of the catchment land area) and the remainder mostly agricultural $(7 \%)^{3}$. Runoff from rainwater and snowmelt carries sediment and agricultural inputs to the lake. Forestry practices underlie the issue, while the hydro-meteorological conditions for the processes are exacerbated by climate change. Eutrophication occurs when the water is overly

${ }^{2}$ https://www.cbag.org.uk

${ }^{3}$ https://www.syke.fi/en-US/Open_information/Spatial_datasets enriched with nutrients, often indicated by blue-green algal blooms, lower water clarity, sliming, higher quantity of mud and reeds on the beaches, as well as reduced oxygen levels for plants and fish. Ecological degradation, in turn, impacts recreational activities such as swimming and fishing as well as livelihoods dependent on the water quality of the lake (tourism and fishing). Additionally, adverse health effects can occur, including skin and eye irritation.

The focus of OPERANDUM NbS work in Puruvesi is on continuous cover forestry (CCF), a sustainable resource management practice involving selective timber harvesting to maintain a forest canopy and vegetation density to reduce runoff while also maintaining forest ecosystem structure and habitat. However, other NbS including constructed wetlands, peak flow control structures, sedimentation ponds and pits and surface runoff fields were also being planned at the time of the survey, as communicated to respondents.

\section{Spercheios River Basin, Greece}

The steep slopes of the Spercheios River Basin, present within approximately two-thirds of the total length of the river, form a mountainous topography with relatively high flooding peaks and very intense sediment yield. In the last downstream part of the Spercheios course, the topography gradually changes into a lowland relief, discharging into the Maliakos Gulf connected to the Aegean Sea. Our research concentrates on the mouth of the Spercheios River near the city of Lamia, the area with the largest population exposed to flooding. Topography, soil properties and climate are conducive to seasonal flash-flooding and high sedimentation. Along with some tourism, agriculture is the most common livelihood in the area.

Flood events occur on an almost yearly basis that damage property-both residential and agricultural-and can block access roads. Most recently, flash flooding in 2018 caused extensive damage and disruption for several weeks. Tourism and agricultural livelihoods are thereby affected in addition to transportation and recreation. There are no recorded deaths from flooding.

A system of canals and trenches, most of which have been in place since the 1950s, are the primary flood protection measures in the basin. Berms are also in place to provide protection near settlements. These measures have been maintained and extended in the past decades with varying degrees of (mostly limited) success.

$\mathrm{NbS}$ in Spercheios are natural water retention measures (NWRM). Drainage basins using natural materials are being implemented to reduce the risk of flooding by absorbing excess water while also providing wildlife habitat and contributing to groundwater recharge and irrigation needs. In parallel, measures such as dam height reduction and the removal of some longitudinal barriers are being taken to increase river connectivity and support downstream wetlands.

\section{METHODS}

\section{Survey Sampling}

Self-administered surveys of residents living near NbS deployment sites in the OPERANDUM project were conducted between September 2019 and April 2020. The 
TABLE 1 | Characteristics of the data collection process and outcomes for each of the three study sites.

\begin{tabular}{|c|c|c|c|c|c|c|c|}
\hline Study site & Survey date & Format & $\begin{array}{l}\text { Collection } \\
\text { method }\end{array}$ & Detailed description & $\begin{array}{l}\text { Response } \\
\text { rate (\%) }\end{array}$ & $\begin{array}{l}\text { Survey } \\
\text { count }\end{array}$ & $\begin{array}{c}\text { Survey count } \\
\text { after pre- } \\
\text { processing }\end{array}$ \\
\hline Catterline & September 2019 & $\begin{array}{l}\text { Paper- } \\
\text { based }\end{array}$ & Door-to-door & $\begin{array}{l}\text { Seventy-two residences were included in the } \\
\text { study area and contacted by the lead author, } \\
\text { first with a survey notification letter one week } \\
\text { prior to visiting the community. The lead author } \\
\text { went door-to-door to every residence and all } \\
\text { over 18-year-old residents were invited to } \\
\text { complete the survey. Surveys were left with } \\
\text { residents to be self-administered and collected } \\
\text { within several days at the respondents' } \\
\text { convenience. Surveys were completed at } 60 \\
\text { residences }\end{array}$ & $47.2^{\mathrm{a}}$ & 67 & 66 \\
\hline Puruvesi & $\begin{array}{c}\text { March-April } \\
2020\end{array}$ & $\begin{array}{l}\text { Online } \\
\left(\text { eHarava }^{\mathrm{b}}\right)\end{array}$ & $\begin{array}{l}\text { Postcard with } \\
\text { online survey link }\end{array}$ & $\begin{array}{l}\text { First, all 1,662 households within the most } \\
\text { affected postal code area (also where the NbS } \\
\text { are planned) were contacted with a postcard } \\
\text { describing the NbS work and inviting } \\
\text { participation in the survey through a URL link. } \\
\text { Next, } 900 \text { members of a local action group of } \\
\text { lake users, ProPuruvesi, were also sent a } \\
\text { survey notification email with invitation (an } \\
\text { estimated } 20 \% \text { of whom were already } \\
\text { contacted through the postcard). A short } \\
\text { article in a free local newspaper was published } \\
\text { in March } 2020 \text { that introduced the project and } \\
\text { the NbS as well as informing/reminding } \\
\text { readers of the ongoing survey }\end{array}$ & 10.3 & 228 & 205 \\
\hline Spercheios & $\begin{array}{l}\text { October 2019- } \\
\text { January } 2020\end{array}$ & $\begin{array}{l}\text { Paper- } \\
\text { based }\end{array}$ & $\begin{array}{l}\text { Focus group, } \\
\text { convenience }\end{array}$ & $\begin{array}{l}\text { First, surveys were distributed at the end of a } \\
\text { public outreach focus group organized within } \\
\text { the context of the OPERANDUM project in the } \\
\text { town of Kompotades in October } 2019 \text {. Thirty } \\
\text { surveys were collected from the focus group, } \\
\text { to which all surrounding residents were invited. } \\
\text { In November } 2019,70 \text { additional paper or } \\
\text { electronic versions of the survey were } \\
\text { distributed to residents by project partners } \\
\text { representing the municipality of Lamia using } \\
\text { existing institutional mailing lists and contacts }\end{array}$ & 79 & 85 & 84 \\
\hline
\end{tabular}

${ }^{a}$ Based on Scottish Census (2011) output area S00091368; https://www.scotlandscensus.gov.uk/ods-web/area.html.

${ }^{b}$ www.eharava.fi.

Covid-19 pandemic had not yet affected the study areas at the time of data collection. Ethical clearance for data collection was granted by a dedicated review board at the University of Glasgow and all responses were voluntary and treated anonymously. Due to time and financial constraints, the sampling approaches in the three sites were non-random and aimed to maximize the number of responses rather than ensure representative samples. Due to different contexts and capacities of local collaborators, this meant data collection methods across the sites were distinct (Table 1).

The samples included mostly even distributions of gender in Catterline and Spercheios and about 60\% more males than females in Puruvesi. The sample in Puruvesi was also older, while the sample in Spercheios was younger than the other sites (Figure 2).

\section{Measured Variables}

We used exploratory factor analyses (EFA) to derive measured variables for attitudinal acceptance, behavioral acceptance, and variables related to the themes of risk, nature, and place.
The survey primarily included 1-9 Likert items and several yes/no items (full surveys are provided in Supplementary Text S1-S3). This Likert range was selected since acceptance is a bipolar construct (i.e., rejection is also possible) (Boateng et al., 2018) and to capture more variation in responses past the mid-point response, given evidence of generally high acceptance of the measures in the sites through past outreach. We used EFA with promax rotation to interpret oblique factors (Abdi 2003) and generate weighted sum factor scores for scales based on Likert items (Briggs and Cheek 1986; Fabrigar et al., 1999; DiStefano et al., 2009; Boateng et al., 2018) while yes/no responses were coded as $1 / 0$ and summed.

We assessed attitudinal acceptance with 13 items due to its lack of established relevant scales and multi-dimensionality based on the five themes of 1) trust in implementers, 2) competing societal interests, 3) sense of personal responsibility, 4) perceived effectiveness of $\mathrm{NbS}$, and 5) acceptance of $\mathrm{NbS}$ cost. We also included two general items related to whether the $\mathrm{NbS}$ is perceived as "good" and whether the respondent is "satisfied 


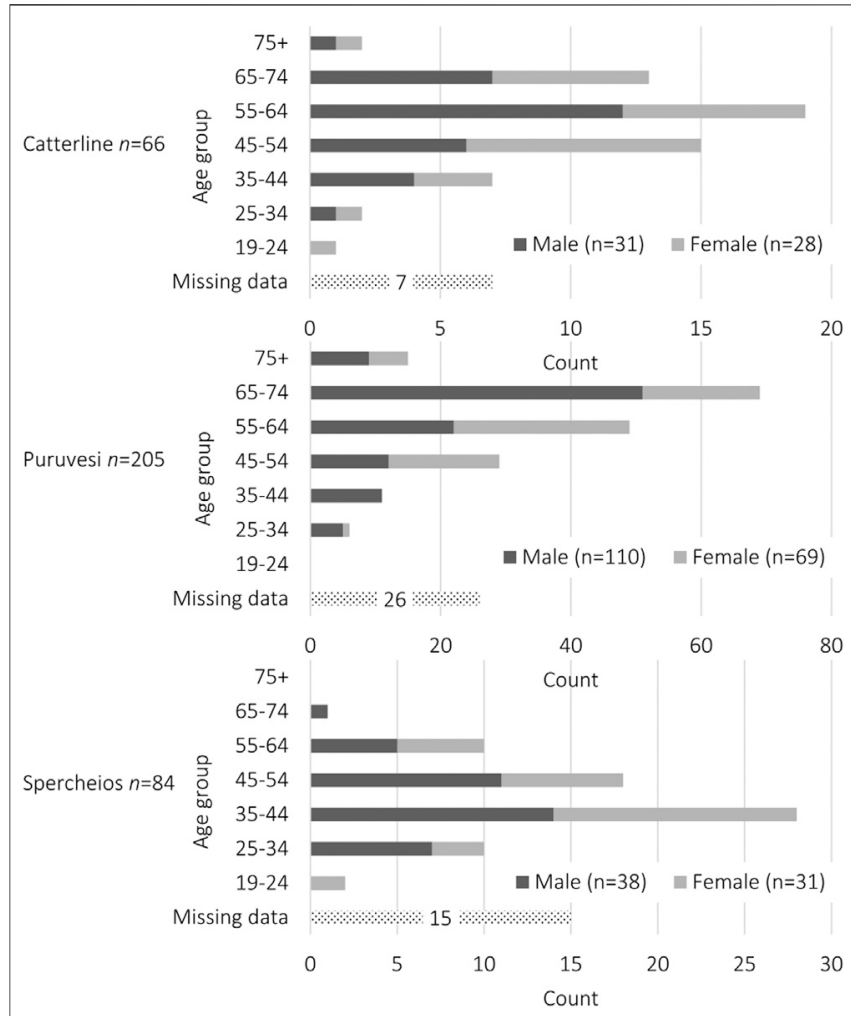

FIGURE 2 | Distribution of male and female respondents in the three study sites by age group. Respondents were explicitly instructed to skip this survey item if they preferred not to respond.

with (ongoing) implementation." The attitudinal acceptance themes and all risk, nature and place variables were drawn from the Anderson and Renaud (2021) review on public acceptance of $\mathrm{NbS}$. Variables were selected that are 1) the most frequently cited as influencing public acceptance of $\mathrm{NbS}, 2$ ) broadly relevant for distinct $\mathrm{NbS}$ contexts, including our study sites, and 3) can be assessed using nonintrusive citizen surveys (e.g., do not test for or require extensive $\mathrm{NbS}$ knowledge). Additionally, we relied on consultation with local project managers at each of the study sites to ensure the relevance of the variables.

For behavioral acceptance, we used six items to reflect the most relevant forms of both passive and active engagement in the sites_ "I would like to ... : "learn about NbS," "attend meetings," "implement and maintain," "monitor," "fundraise or source supplies" (not applicable in Spercheios), or "volunteer in other ways". These items were designed to capture the wide range of potential forms of acceptance identified in Anderson and Renaud (2021). They were determined in consultation with local project managers to 1) include the full range of past supportive actions of residents, 2) include potential future actions that would be instrumentally useful for the project managers (i.e., more than merely performative), 3) be relevant across $\mathrm{NbS}$ contexts (i.e., not overly specific to the sites), and 4) capture a range of knowledge, skill, and physical capacities of residents. This latter criterion was particularly important given the substantial elderly population in the Catterline and Puruvesi sites.
We use scales, i.e., internally reliable compositions of multiple survey items that measure a single concept (Borsboom 2005), for attitudinal acceptance (13 items) and behavioral acceptance (6), as well as for variables within the themes of risk, nature, or place. These include: risk perception (5), risk intolerance (4-6), past impacts (5-8), future impacts (5-8), commitment to nature (4), and connectedness to place 4) (Table 2). Risk scales (excluding risk perception) vary in number of items due to the number of relevant hazard impacts identified per site (Supplementary Text S1-S3). To capture the environmental aspect of an item related to attitudinal acceptance, "sense of responsibility for risk reduction," we included the additional single item-responsibility for nature (Blake 1999). We use the term "variables" to refer to all survey items and scales, with the exception of EFA results for attitudinal acceptance, which we refer to as "factors".

The commitment to nature scale is based on Davis et al's. (2011) commitment to the environment scale and the connectedness to place scale on Jorgensen and Stedman (2001). These were truncated due to space constraints (Buijs 2009) and to prevent respondent fatigue and/or criticism of seemingly irrelevant survey material. Risk perception scales relevant to natural hazards in academic literature have historically focused primarily on hazard characteristics (Fischhoff et al., 1978; Slovic et al., 1985; Siegrist and Árvai 2020). Perceived vulnerability and concern (or "worry") have also been associated with risk perception and protective behavior and engagement (Rundmo 2002; Peters et al., 2006; Gifford and Comeau 2011; Terpstra 2011). We combined items related to perceived hazard, vulnerability, and concern and created additional scales of summed binary past impacts (experienced) and future impacts (expected). The risk intolerance scale was inspired by Finlay and Fell (1997), who applied the concept to individual perception of landslide risk, Maynard et al. (1976), who assessed acceptability of risks associated with nuclear waste disposal, and Haynes et al. (2008), who assessed tolerability of volcanic risk.

Generally, the scales yielded appropriate alpha scores. Truncating the scales decreased their reliability and necessitated, in some cases, the iterative exclusion of items on a site-by-site basis (see Supplementary Table S1 for a list of retained/excluded variables per site) (Boateng et al., 2018). The risk perception scale showed the lowest reliability scores. Due to several low scores, we conducted a final analysis using all underlying single items in addition to the survey scales.

Space was provided periodically for respondents to write in "survey comments," which we assessed to help interpret the results. Translations were carried out by the authors.

\section{Data Pre-Processing and Analysis}

Data pre-processing was carried out using Excel and analysis carried out using SPSS (v. 26). Responses with high missing data counts ( $n=14$ in Puruvesi) or with lack of expressed consent were removed ( $n=5$ in Puruvesi; $n=1$ in Spercheios). Due to small sample sizes in Catterline and Spercheios, single missing values for scale items were imputed using the median of other items for the same scale and respondent (Bernaards and Sijtsma 2000). 
TABLE 2 | Composition and computation of variable scales. For scales composed of 1-9 Likert items, processing and reliability testing was conducted by assessing Cronbach's alpha (a), corrected-item-total correlations (CITC), and exploratory factor analysis (EFA) using principal axis factoring. The "original" Cronbach's a is a measure of the internal reliability of all scale items per site ( $\mathrm{C}=$ Catterline, $\mathrm{P}=$ Puruvesi, and $\mathrm{S}=$ Spercheios), while the "final" Cronbach's a results from removing items from the scales to increase their reliability, based on the processing steps described. Factor scores using weighted averages were calculated for further analysis.

\begin{tabular}{|c|c|c|c|c|c|c|c|}
\hline Scales $^{a}$ & $\begin{array}{c}\text { Risk } \\
\text { perception }\end{array}$ & Risk intolerance & Past impacts & Future impacts & $\begin{array}{l}\text { Commitment } \\
\text { to nature }\end{array}$ & $\begin{array}{c}\text { Responsibility for } \\
\text { nature }\end{array}$ & $\begin{array}{c}\text { Connectedness } \\
\text { to place }\end{array}$ \\
\hline Item count & 5 & $4-6$ & $5-8$ & $5-8$ & 4 & 1 & 4 \\
\hline Agg. method & Factor score & Factor score & Sum & Sum & Factor score & $\mathrm{N} / \mathrm{A}$ & Factor score \\
\hline $\begin{array}{l}\text { Themes/item } \\
\text { structure }\end{array}$ & $\begin{array}{l}\text { Coping } \\
\text { capacity } \\
\text { Susceptibility } \\
\text { Hazard } \\
\text { frequency } \\
\text { Hazard } \\
\text { magnitude } \\
\text { Concern }\end{array}$ & $\begin{array}{l}\text { "It is okay if [exposed } \\
\text { element] is/are } \\
\text { affected by [hazard] } \\
\text { once every [time } \\
\text { span]." }\end{array}$ & $\begin{array}{l}\text { "In the past, } \\
\text { [hazard] has } \\
\text { affected my } \\
\text { [exposed } \\
\text { element] in } \\
\text { [place]." }\end{array}$ & $\begin{array}{l}\text { "In the future, I } \\
\text { believe [hazard] will } \\
\text { affect my [exposed } \\
\text { element] in [place]." }\end{array}$ & $\begin{array}{l}\text { Well-being } \\
\text { Attachment } \\
\text { Feel good } \\
\text { Best interests }\end{array}$ & $\begin{array}{l}\text { "As a resident of [place], I } \\
\text { feel responsible for } \\
\text { protecting its natural } \\
\text { environment." }\end{array}$ & $\begin{array}{l}\text { Identity } \\
\text { Attachment } \\
\text { Dependence } \\
\text { Pride }\end{array}$ \\
\hline $\begin{array}{l}\text { Original } \\
\text { Cronbach's a }\end{array}$ & $\begin{array}{l}C=0.491 \\
P=0.630 \\
S=0.576\end{array}$ & $\begin{array}{l}C=0.864 \\
P=0.854 \\
S=0.851\end{array}$ & N/A & $\mathrm{N} / \mathrm{A}$ & $\begin{array}{l}C=0.887 \\
P=0.587 \\
S=0.564\end{array}$ & $\mathrm{~N} / \mathrm{A}$ & $\begin{array}{l}C=0.734 \\
P=0.668 \\
S=0.724\end{array}$ \\
\hline $\begin{array}{l}\text { Final } \\
\text { Cronbach's } \alpha\end{array}$ & $\begin{array}{l}C=0.550 \\
P=0.653 \\
S=0.728\end{array}$ & $\begin{array}{l}C=0.864 \\
P=0.854 \\
S=0.839\end{array}$ & $\mathrm{~N} / \mathrm{A}$ & $\mathrm{N} / \mathrm{A}$ & $\begin{array}{l}C=0.887 \\
P=0.759 \\
S=0.695\end{array}$ & $\mathrm{~N} / \mathrm{A}$ & $\begin{array}{l}C=0.771 \\
P=0.651 \\
S=0.776\end{array}$ \\
\hline $\begin{array}{l}\text { Final\% } \\
\text { variance } \\
\text { explained }\end{array}$ & $\begin{array}{l}C=69.2 \\
P=51.1 \\
S=56.0\end{array}$ & $\begin{array}{l}C=72.6 \\
P=81.2 \\
S=62.3\end{array}$ & N/A & $\mathrm{N} / \mathrm{A}$ & $\begin{array}{l}C=75.4 \\
P=68.0 \\
S=63.1\end{array}$ & $\mathrm{~N} / \mathrm{A}$ & $\begin{array}{l}C=72.8 \\
P=59.5 \\
S=69.9\end{array}$ \\
\hline
\end{tabular}

\section{Scale processing steps}

1. Compute Cronbach's alpha scores, alpha if item deleted and corrected-item-total correlations (CITC)

2. In parallel, run EFA using principal axis factoring (100 iterations max), eigenvalues 1, and promax rotation (100 iterations max)

3. Remove items from each EFA model until the following criteria are met, in this general order of importance: alpha maximized; no CITC <0.3; no communality <0.3; no crossloading factors, low loadings on all factors, or stand-alone large negative loadings; percent variance maximized; adequate KMO and Bartlett's test

4. Rerun this process iteratively, removing one variable at a time

5. Calculate weighted averages (non-refined factor score method) to use for further analysis

${ }^{a}$ Responsibility for nature is a single item.

Additionally, "I don't know" responses, included on Catterline and Spercheios surveys, were treated as mid-point responses (5) on the scales for risk perception, risk intolerance, and attitudinal acceptance. Items with greater than $5 \%$ imputed data per site are shown in supplementary material, along with data imputation for binary hazard impact items (Supplementary Table S2).

The data analysis process was guided by the three research questions and required defining attitudinal acceptance and behavioral acceptance and then running correlation and regression analyses to determine their relation to risk, nature, and place variables. The results subsections are organized based on the three research questions and corresponding analyses (Figure 3).

First, responses to attitudinal and behavioral acceptance items were divided by the max Likert response ( 9 for Catterline and Spercheios, 7 for Puruvesi) and arithmetic means calculated to compare the standardized degree of acceptance within and across the sites. Pairwise Mann-Whitney $U$ tests were used to determine any significant differences in means between sites $(p>0.05)$.
We used exploratory factor analysis (EFA) to determine the items that best define the constructs of attitudinal and behavioral acceptance towards $\mathrm{NbS}$ in the sites (see Table 2 for EFA methodology; Supplementary Tables S3, S4 for detailed outputs). We then conducted Spearman's rho ( $\rho$ ) correlations between both attitudinal and behavioral acceptance and the survey variables related to risk, nature, and place. The correlation analyses allowed us to explore independent associations between acceptance and individual variables. We only report correlations at significance levels of $p<0.10, p<0.05$, and $p<0.01$ to simplify visual interpretation of tables.

Multiple linear regression models, in contrast to the correlations, are affected by interrelations among the variables. These were also created using each of the risk, nature, and place variables per site as well as models including all survey variables per site to explain variance in behavioral acceptance. For the latter, we included only predictors with the strongest correlations with behavioral acceptance, maximum one predictor per eight observations (Wilson VanVoorhis and Morgan, 2007). We 


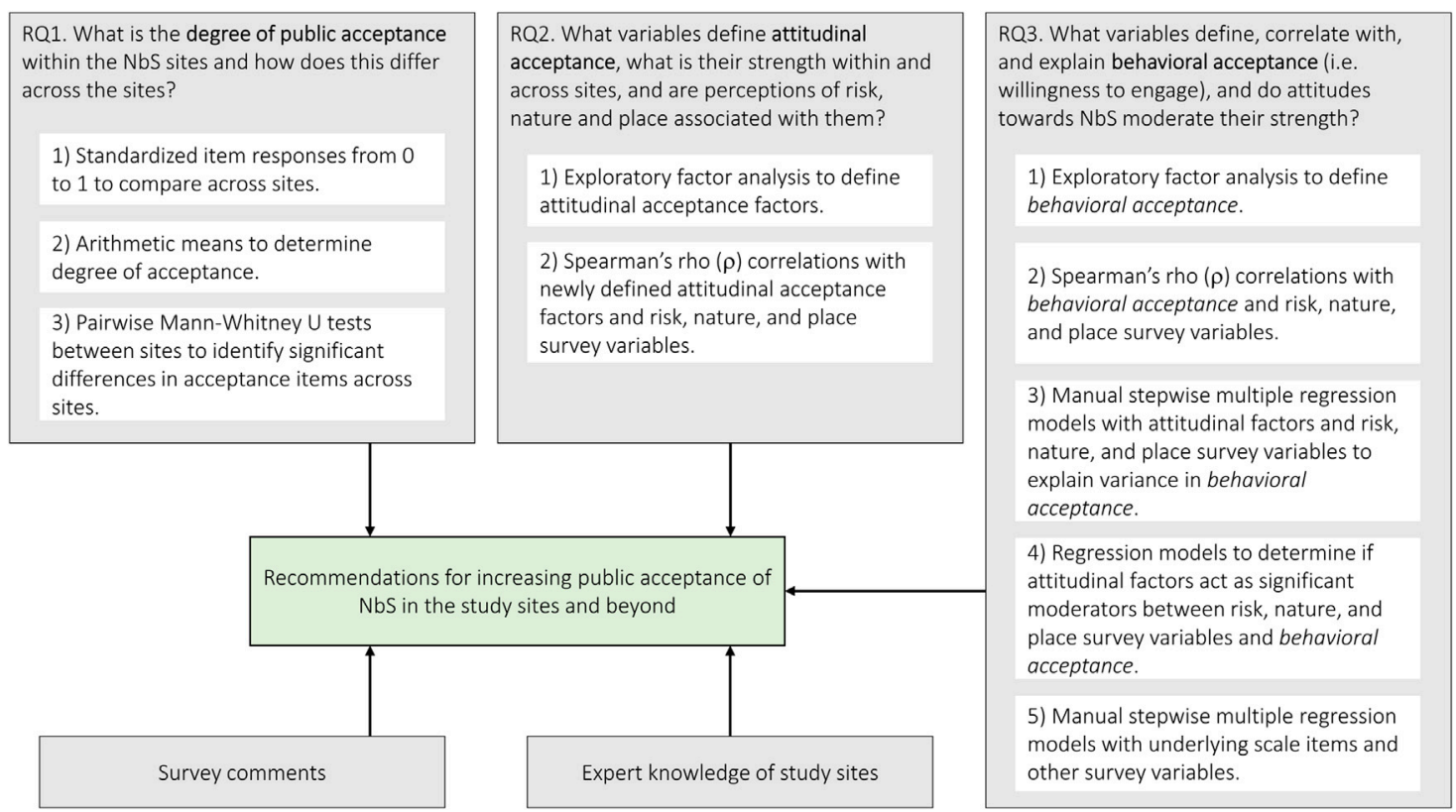

FIGURE 3|Research questions $(R Q)$ and corresponding methods. Statistical results, combined with survey comments and expert knowledge of the sites, lead to recommendations for increasing public acceptance of $\mathrm{NbS}$ both within the study sites and for NbS generally.

followed a manual stepwise procedure of iteratively removing (stepdown) the most non-significant predictors until all remaining predictors were significant to at least $p<0.05$. This is preferred in contrast to relying on automated stepwise regression with biased selection criteria and overemphasis on overall model fit indices (Thompson 1995). It is important to note that excluded predictors are not necessarily insignificant in simple regression models (and therefore relevant) but rather, taken together, do not explain additional variance. Since this method increases the chance of Type I errors within final models, despite all predictor variables grounded in theory as relevant for public acceptance of $\mathrm{NbS}$, we interpreted findings also using correlation outputs, expert knowledge of the sites and qualitative survey comments. The risk, nature, and place variables may be considered underlying personal values and related to affective reactions to $\mathrm{NbS}$, whereas attitudes towards $\mathrm{NbS}$ are more analytically driven (i.e., arrived at through reasoning) (Homer and Kahle, 1988; Slovic et al., 2004; Jacobs and Buijs 2011). Therefore, attitudinal acceptance of NbS may moderate the strength of the risk, nature, and place variables on behavioral intention. We created moderating regression models using the PROCESS macro for SPSS (Hayes 2017) with attitudinal acceptance factor scores as moderating variables for all risk, nature, and place variables.

\section{RESULTS}

\section{RQ1. What is the Degree of Public Acceptance Within and Across the Sites?}

Standardized mean responses across the sites show a positive perception of the $\mathrm{NbS}$ generally in that their implementation is considered "good" $\left(\mathrm{M}_{\text {Catterline }}=0.92 / 1, \mathrm{SE}=0.022 ; \mathrm{M}_{\text {Puruvesi }}=0.93\right.$ / $\left.1, \mathrm{SE}=0.010 ; \mathrm{M}_{\text {Spercheios }}=0.86 / 1, \mathrm{SE}=0.023\right)$. However, there were lower responses for the degree of satisfaction with how the measures are being implemented $\left(\mathrm{M}_{\text {Catterline }}=0.75 / 1, \mathrm{SE}=0.027 ; \mathrm{M}_{\text {Puruvesi }}=\right.$ $\left.0.79 / 1, \mathrm{SE}=0.016 ; \mathrm{M}_{\text {Spercheios }}=0.66 / 1, \mathrm{SE}=0.025\right)$ and their perceived effectiveness $\left(\mathrm{M}_{\text {Catterline }}=0.71 / 1, \mathrm{SE}=0.024 ; \mathrm{M}_{\text {Puruvesi }}\right.$ $\left.=0.56 / 1, \mathrm{SE}=0.024 ; \mathrm{M}_{\text {Spercheios }}=0.72 / 1, \mathrm{SE}=0.023\right)$ (Figure 4).

Spercheios stands out as a unique study site among the three regarding acceptance, with nine attitudinal acceptance items significantly lower than the other two sites and four behavioral acceptance items significantly higher than the other two sites (Mann-Whitney $U p<0.05$ ). There is generally greater skepticism surrounding the measures and implementers in Spercheios but more willingness to actively support them. The discrepancy in acceptance values in Spercheios demonstrates the important distinction between the two forms of acceptance.

Greater skepticism in Spercheios is likely in part due to past failed flood protection measures in the region and a mistrust of authorities (Georghiou 1996). This may play a role in the perceived importance of cost as well-a significantly stronger potential limiting variable for acceptance among residents of Spercheios $(\mathrm{M}=0.64 / 1, \mathrm{SE}=0.026$; Mann-Whitney $U$ $p<0.05)$ and significantly less of a barrier to acceptance in Puruvesi $(\mathrm{M}=0.80 / 1, \mathrm{SE}=0.017$; Mann-Whitney $U p<0.05)$. Two items related to effectiveness, "NbS will reduce risk in the future" and "(do not) need more evidence NbS will work," have the two lowest average standardized scores across the sites. The other item related to effectiveness describes fatalist or agentic views of the risk, "risk can be reduced," and had the second highest average scores summed across the sites. This indicates that the skepticism regarding effectiveness of risk reduction originates from the 


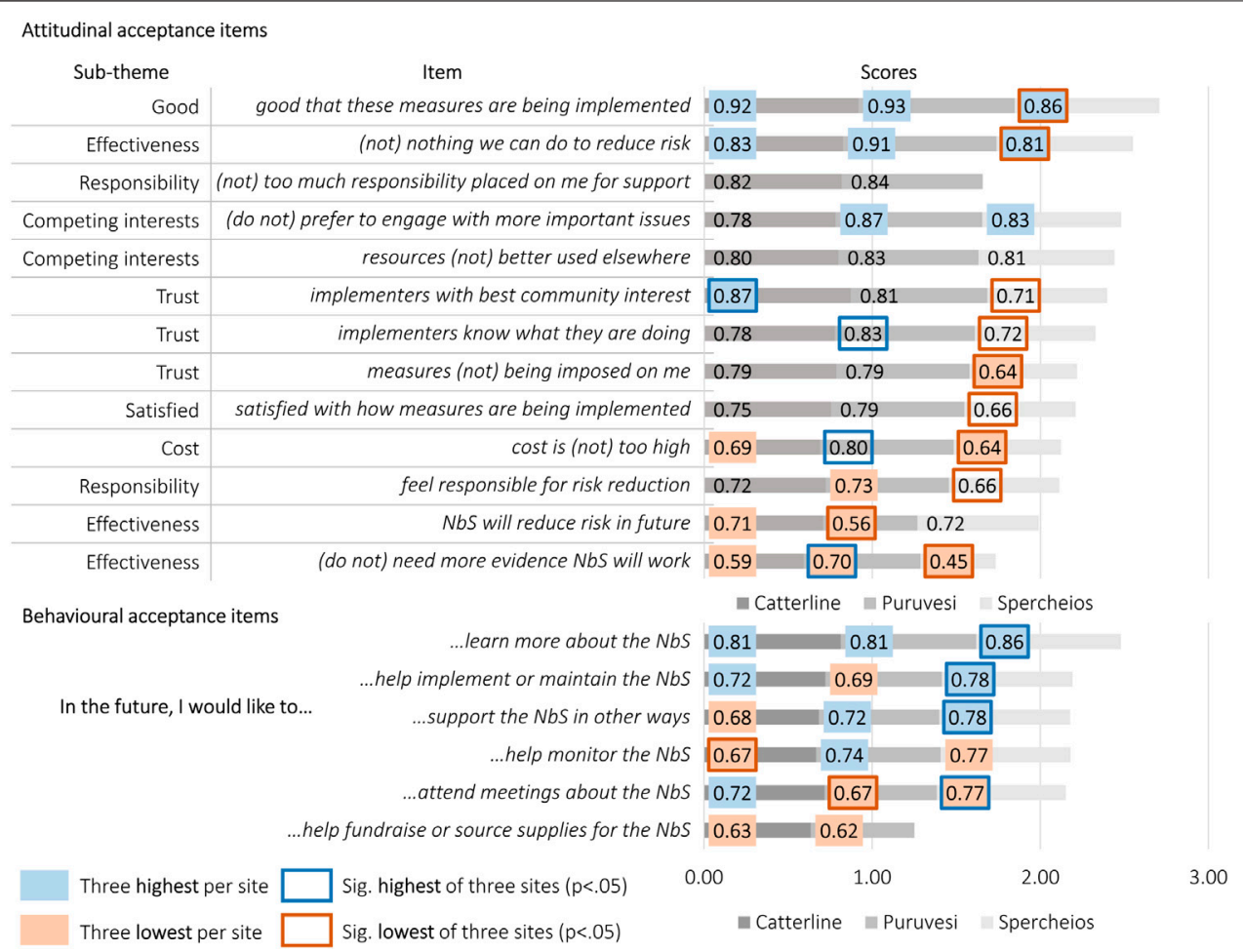

FIGURE 4 | Standardized average responses for survey items that represent attitudinal acceptance and behavioral acceptance in the three study sites. Response averages are standardized by dividing by the maximum Likert response ( 9 for Catterline and Spercheios and 7 for Puruvesi), so that 1 is the new maximum value and 0 the minimum. Attitudinal and behavioral items are ordered from top to bottom by highest sum of the average responses across the sites. The top three highest average responses for each site for each form of acceptance are highlighted in blue and the three lowest highlighted in red. Using Mann-Whitney $U$ tests, the items that are significantly higher in one site compared to each of the other two sites $(p<0.05)$ are outlined in blue and those significantly lower in red. The third attitudinal acceptance item from the top regarding responsibility and the last behavioral acceptance item were excluded from surveys conducted in Spercheios since they were not applicable.

specific nature-based solutions rather than from a sense of hopelessness or inevitability.

In both Catterline and Spercheios, there were also a high number of mid-point responses on the Likert item regarding satisfaction in implementation (Catterline $\mathrm{n}=14$; Spercheios $\mathrm{n}=$ 14) and items related to trust, particularly "implementers know what they are doing" (Catterline $\mathrm{n}=20$; Spercheios $\mathrm{n}=23$ ). This most likely represents either a lack of information and/or a "wait and see" mind-set, since all NbS were in the pre-implementation phase when the surveys were completed. This mind-set has been prominent in past community outreach activities in Catterline. Items for behavioral acceptance show high public demand for both more passive and active forms of engagement with the $\mathrm{NbS}$ project. Full descriptive statistics of acceptance items are provided in supplementary material (Supplementary Table S5).

\section{RQ2. Attitudinal Acceptance What Defines Attitudinal Acceptance?}

The composition of attitudinal acceptance of $\mathrm{NbS}$ in the three sites is defined using principal axis factoring. Based on factor loadings, three distinct dimensions of attitudes emerged from the data across the sites. Based on the highest loading factors, we named these: trust in implementers, benefits outweigh costs, and good and satisfied (Table 3).
The factor composition and item loadings are mostly divergent across the sites. It is likely that the unique attributes of each rural $\mathrm{NbS}$ site for risk reduction led to differences in the strength of the attitudinal acceptance themes and their interrelations. A more comprehensive list of survey items for these themes, and the inclusion of additional themes, may have consistently captured unique dimensions of attitudinal acceptance. However, the reasonable percent variance explained (Catterline 62.21\%; Puruvesi $73.85 \%$; and Spercheios 79.18\%) and the emergence of three unique factors with similarly loading items when considering all three sites suggests that perceptions in relation to trust in implementers, benefits outweigh costs, and good and satisfied with the $\mathrm{NbS}$ should be considered when assessing attitudinal acceptance.

The first two items related to trust in the implementers were retained together within a factor for all three of the sites. Trust is a particularly large component of acceptance in Spercheios, where the factor composed of these two items explains $53.15 \%$ of the variance in attitudes. Different past experiences with flood risk reduction measures and the authorities responsible for them is likely to be crucial here, also supported by the highest standard deviation of scores for these items in Spercheios at SD $=0.24$ for each (compared to $\mathrm{SD}_{\text {Catterline }}=0.18 ; \mathrm{SD}_{\text {Puruvesi }}=0.19,0.21$ ). Results suggest that 1) trust towards the implementers of $\mathrm{NbS}$ is a unique dimension of acceptance (Spercheios and Puruvesi), and 
TABLE 3 | (A) Rotated structure matrix output (promax) from principal axis factoring to determine latent variables of attitudinal acceptance in each of the three study sites. Items were standardized for direction when necessary so that increasing scores equated to increasing acceptance. All items were first included and iteratively removed one-by-one from the analysis to maximize reliability and percent variance explained within each site. Two dimensions of attitudinal acceptance best explain the variance in each site. Only the higher factor loading between each of the two factors (F1 and F2) per item is shown here, since these were used to derive weighted average factor scores for further analyses. For full scale reliability and EFA outputs (initial and final, after iterative item removal) see supplementary material (Supplementary Table S3).

Panel A

\begin{tabular}{|c|c|c|c|c|c|c|c|}
\hline & & \multicolumn{2}{|c|}{ Catterline } & \multicolumn{2}{|c|}{ Puruvesi } & \multicolumn{2}{|c|}{ Spercheios } \\
\hline & Analysis $n$ & \multicolumn{2}{|c|}{66} & \multicolumn{2}{|c|}{181} & \multicolumn{2}{|c|}{84} \\
\hline & Total percent variance explained & \multicolumn{2}{|c|}{62.21} & \multicolumn{2}{|c|}{73.85} & \multicolumn{2}{|c|}{79.18} \\
\hline & Cronbach's alpha (a) & \multicolumn{2}{|c|}{0.840} & \multicolumn{2}{|c|}{0.747} & \multicolumn{2}{|c|}{0.704} \\
\hline & Lowest corrected item-total correlation (CITC) & \multicolumn{2}{|c|}{0.406} & \multicolumn{2}{|c|}{0.442} & \multicolumn{2}{|c|}{0.427} \\
\hline & Lowest communality & \multicolumn{2}{|c|}{0.404} & \multicolumn{2}{|c|}{0.350} & \multicolumn{2}{|c|}{0.501} \\
\hline & Factor & $\mathbf{F 1}$ & F2 & $\mathbf{F 1}$ & F2 & $\mathbf{F 1}$ & $\mathbf{F 2}$ \\
\hline & Factor percent variance explained & 46.03 & 16.18 & 50.53 & 23.32 & 53.15 & 26.04 \\
\hline Theme & Item & & & & & & \\
\hline Good & It is good that these measures are being implemented & 0.724 & & & & & 0.707 \\
\hline Satisfied & I am satisfied with how these measures are being implemented & 0.761 & & & & & 0.762 \\
\hline Trust & I believe the people implementing the measures know what they are doing & 0.657 & & & 0.921 & 0.742 & \\
\hline Trust & I believe the people implementing the measures are doing so in the best interest of the community & 0.635 & & & 0.741 & 0.819 & \\
\hline Trust & I (do not) feel that the measures are being imposed on me & & & 0.629 & & & \\
\hline $\begin{array}{l}\text { Competing } \\
\text { interests }\end{array}$ & I believe resources would (not) be better used for other community concerns & & 0.686 & 0.909 & & & \\
\hline $\begin{array}{l}\text { Competing } \\
\text { interests }\end{array}$ & $\begin{array}{l}\text { I would (not) prefer to engage with more important community issues than (hazard) risk reduction } \\
\text { in (place) }\end{array}$ & 0.608 & & & & & \\
\hline Effectiveness & I (do not) need more evidence that the natural measures will reduce risk of (hazard) & & 0.725 & & & & \\
\hline Effectiveness & I believe that when (storms) come in the future, these measures will reduce the chance of (hazard) & 0.712 & & & & & \\
\hline Cost & I believe the financial cost of these measures is (not) too great & & 0.667 & 0.591 & & & \\
\hline
\end{tabular}

Panel B

Factor 1

Catterline

Spercheios

Puruvesi
Good and satisfied

Trust in implementers

Benefits outweigh costs
Factor 2

Benefits outweigh costs Good and satisfied Trust in implementers
2) trust is a consistently important factor for attitudes towards NbS.

Respondents' views regarding competing societal interests, the cost of the NbS, and whether the NbS are "good" and respondents are "satisfied" with their implementation are each retained in two of the three sites. In Puruvesi, perceptions of whether benefits outweigh costs explain just over $50 \%$ of the variance in attitudes (factor $1 ; 50.53 \%$ ). An item a priori linked to trust in implementers ("measures being imposed on me") loads with the themes competing interests and cost in Puruvesi (0.629), suggesting it is also more related to a cost/benefit judgement of the measures.

Both items designed to capture respondents' sense of responsibility for risk reduction and an item related to an agentic vs. fatalistic view of risk ( $a$ priori grouped with effectiveness variables; "risk can be reduced") were excluded based on low scores for alpha, CITC, and communality (Supplementary Table S3).

\section{What Correlates with Attitudinal Acceptance?}

Spearman's rho $(\rho)$ correlations show consistently moderate significant correlations of most variables in Catterline and Puruvesi and only risk intolerance and commitment to nature in Spercheios (Table 4). We show here only correlations of at least $p<0.10$ to ease interpretation of the findings.

Commitment to nature is a significant correlate across all three attitudinal acceptance factors and sites. It is particularly associated with respondents' perception of benefits versus costs in Puruvesi $(\rho=0.518, p<0.01)$, as is responsibility for nature ( $\rho=$ $0.324, p<0.01)$. This is unsurprising since the hazard of eutrophication is itself a degradation of the natural environment. However, the correlation of $\rho=0.340(p<0.01)$ 
TABLE 4 | Spearman's rho $(\rho)$ correlation coefficients of attitudinal acceptance factors and risk, nature, and place survey variables in the three study sites. Only correlations significant to at least $p<0.10$ are shown.

\begin{tabular}{|c|c|c|c|c|c|c|}
\hline & \multicolumn{2}{|c|}{ Good and satisfied } & \multicolumn{2}{|c|}{ Benefits outweigh costs } & \multicolumn{2}{|c|}{ Trust in implementers } \\
\hline & Catterline & Spercheios & Catterline & Puruvesi & Spercheios & Puruvesi \\
\hline \multicolumn{7}{|l|}{ Risk } \\
\hline Risk perception & $0.345^{\mathrm{a}}$ & & & $0.340^{\mathrm{a}}$ & & $0.304^{a}$ \\
\hline Risk intolerance & $0.261^{b}$ & $0.426^{a}$ & & $0.193^{\mathrm{a}}$ & $0.257^{b}$ & $0.125^{\mathrm{C}}$ \\
\hline Past impacts (sum) & $0.401^{a}$ & & & $0.142^{\mathrm{C}}$ & & \\
\hline Future impacts (sum) & $0.489^{a}$ & & & $0.212^{\mathrm{a}}$ & & $0.178^{b}$ \\
\hline \multicolumn{7}{|l|}{ Nature } \\
\hline Commitment to nature & $0.319^{a}$ & $0.231^{\mathrm{b}}$ & $0.229^{c}$ & $0.518^{\mathrm{a}}$ & $0.207^{\mathrm{c}}$ & $0.301^{a}$ \\
\hline Responsibility for nature & $0.308^{b}$ & & & $0.324^{a}$ & & $0.179^{b}$ \\
\hline \multicolumn{7}{|l|}{ Place } \\
\hline Connectedness to place & $0.425^{\mathrm{a}}$ & & & $0.225^{\mathrm{a}}$ & & $0.240^{\mathrm{a}}$ \\
\hline
\end{tabular}

${ }^{a} p<0.01$

${ }^{b} \mathrm{p}<0.05$.

${ }^{c} p<0.10$.

with risk perception also indicates the intersection between risk and nature in relation to acceptance at the site.

Risk intolerance is also consistently significant and the strongest correlate of any risk, nature, and place variable for Spercheios, associated there with the factor good and satisfied at $\rho=0.426(p<0.01)$. Puruvesi likely has the most significant correlates due to the larger sample size, serving as an important reminder to triangulate correlation results with other statistical outputs as well as expert knowledge and survey comments.

Testing demographic categorical variables of age and gender using simple linear regression, we found that in Puruvesi, gender and age are predictive of positive attitudes in terms of benefits outweigh costs $\left(\mathrm{F}(1,181)=5.75, p=0.018 ; \mathrm{R}^{2}=0.031 ; \beta=0.192\right.$, $p=0.018)$ and gender is also predictive of trust in implementers $(\mathrm{F}$ $\left.(1,181)=6.46, p=0.012 ; \mathrm{R}^{2}=0.035 ; \beta=0.186, p=0.012\right)$. There, female respondents have significantly more positive attitudes toward the $\mathrm{NbS}$ for benefits outweigh costs and for trust in implementers (Mann-Whitney $U p<0.05$ ) and increasing age predicts increasing positive attitudes of benefits outweigh costs ( $\mathrm{F}$ $\left.(1,181)=6.39, p=0.012 ; R^{2}=0.034 ; \beta=0.185, p=0.012\right)$.

\section{RQ3. Behavioral Acceptance \\ What Defines Behavioral Acceptance?}

Based on principal axis factoring, a single factor captures most of the variance in behavioral acceptance with high internal reliability in all three sites (Catterline: $75.83 \%$ variance explained, Cronbach's $\alpha=0.933$; Puruvesi: $66.29 \%, \alpha=0.898$; Spercheios: $63.81 \%, \alpha=0.856$ ). We therefore retained all items and calculated weighted factor scores for further analyses of a single behavioral acceptance variable for each site (Supplementary Table S4).

\section{What Risk, Nature, and Place Survey Variables Correlate With and Predict Behavioral Acceptance?}

Both the attitudinal acceptance factors and risk, nature, and place variables are consistently and significantly correlated with
TABLE 5 | Spearman's rho $(\rho)$ correlation coefficients of attitudinal acceptance factors and risk, nature, and place survey variables with behavioral acceptance in the three study sites. Only correlations significant to at least $p<0.10$ are shown here. N/A (not applicable) is used when the factor did not define attitudinal acceptance in that site.

\begin{tabular}{|c|c|c|c|}
\hline & \multicolumn{3}{|c|}{ Behavioral acceptance } \\
\hline & Catterline & Puruvesi & Spercheios \\
\hline \multicolumn{4}{|l|}{ Attitudinal acceptance } \\
\hline Good and satisfied & $0.492^{\mathrm{a}}$ & N/A & $0.297^{a}$ \\
\hline Benefits outweigh costs & & $0.327^{\mathrm{a}}$ & N/A \\
\hline Trust in implementers & N/A & $0.223^{a}$ & $0.369^{a}$ \\
\hline \multicolumn{4}{|l|}{ Risk } \\
\hline Risk perception & $0.436^{a}$ & $0.276^{a}$ & $0.252^{b}$ \\
\hline Risk intolerance & & $0.254^{a}$ & $0.264^{b}$ \\
\hline Past impacts (sum) & & $0.319^{a}$ & $0.354^{\mathrm{a}}$ \\
\hline Future impacts (sum) & $0.510^{\mathrm{a}}$ & $0.385^{\mathrm{a}}$ & $0.286^{a}$ \\
\hline \multicolumn{4}{|l|}{ Nature } \\
\hline Commitment to nature & $0.324^{a}$ & $0.395^{\mathrm{a}}$ & \\
\hline Responsibility for nature & $0.396^{\mathrm{a}}$ & $0.410^{\mathrm{a}}$ & $0.219^{b}$ \\
\hline \multicolumn{4}{|l|}{ Place } \\
\hline Connectedness to place & $0.465^{\mathrm{a}}$ & $0.284^{\mathrm{a}}$ & $0.330^{\mathrm{a}}$ \\
\hline
\end{tabular}

behavioral intention across the sites. The attitudinal factor good and satisfied has the second strongest correlation of any variable in Catterline $(\rho=0.492, p<0.01)$ and the attitudinal factor trust in the implementers has the strongest correlation in Spercheios $(\rho=0.369, p<0.01)$ (Table 5).

Although both risk perception and future impacts are significant correlates across the three sites, the latter is more 
TABLE 6 | Multiple linear regression model results using attitudinal factor scores and risk, nature, and place variables as initial independent variables and behavioral acceptance scores as the dependent variable in each study site. Variables are removed from the model in a step-wise manner in order of least significant beta per model, until only beta $(\beta)$ coefficients at $p<0.05$ remain.

\begin{tabular}{|c|c|c|c|c|c|c|c|}
\hline Model & Predictors & $\beta$ & $\mathbf{R}^{2}$ & Adj. $R^{2}$ & $\boldsymbol{F}$ & df & DW \\
\hline \multirow[t]{3}{*}{ Catterline } & & & 0.277 & 0.254 & $12.09^{a}$ & 65 & 1.85 \\
\hline & Risk perception & $0.382^{a}$ & & & & & \\
\hline & $\begin{array}{l}\text { Good and } \\
\text { satisfied }\end{array}$ & $0.256^{b}$ & & & & & \\
\hline \multirow[t]{6}{*}{ Puruvesi } & & & 0.317 & 0.297 & $16.22^{a}$ & 180 & 1.92 \\
\hline & $\begin{array}{l}\text { Responsibility } \\
\text { for nature }\end{array}$ & $0.211^{a}$ & & & & & \\
\hline & $\begin{array}{l}\text { Benefits over } \\
\text { costs }\end{array}$ & $0.208^{a}$ & & & & & \\
\hline & $\begin{array}{l}\text { Future } \\
\text { impacts (sum) }\end{array}$ & $0.173^{b}$ & & & & & \\
\hline & $\begin{array}{l}\text { Past } \\
\text { impacts (sum) }\end{array}$ & $0.162^{b}$ & & & & & \\
\hline & $\begin{array}{l}\text { Connectedness } \\
\text { to place }\end{array}$ & $0.144^{b}$ & & & & & \\
\hline \multirow[t]{5}{*}{ Spercheios } & & & 0.377 & 0.345 & $11.76^{\mathrm{a}}$ & 82 & 1.71 \\
\hline & $\begin{array}{l}\text { Connectedness } \\
\text { to place }\end{array}$ & $0.297^{\mathrm{a}}$ & & & & & \\
\hline & $\begin{array}{l}\text { Past } \\
\text { impacts (sum) }\end{array}$ & $0.287^{a}$ & & & & & \\
\hline & $\begin{array}{l}\text { Trust in } \\
\text { implementers }\end{array}$ & $0.263^{a}$ & & & & & \\
\hline & $\begin{array}{l}\text { Good and } \\
\text { satisfied }\end{array}$ & $0.241^{b}$ & & & & & \\
\hline
\end{tabular}

${ }^{a} p<.01$.

${ }^{b} \mathrm{p}<.05$.

strongly correlated (Catterline $\rho=0.510, p<0.01$; Puruvesi $\rho=$ $0.385, p<0.01$; Spercheios $\rho=0.286, p<0.01$ ). This is in line with past risk perception research showing that perceived consequences are more associated with mitigative or adaptive behavior than hazard characteristics (Sjoeberg 1999).

In Catterline and Puruvesi, respectively, behavioral acceptance (like attitudinal acceptance) is shown to be associated with respondents' commitment to nature ( $\rho=0.324, p<0.01$; $\rho=0.395, p<0.01)$ and responsibility for nature $(\rho=0.396, p<$ $0.01 ; \rho=0.410, p<0.01)$. Landslides in Catterline and eutrophication in Puruvesi are both seen as threats to the ecosystem, in contrast to Spercheios where, despite also being an area of high scenic beauty, the impacts of flooding and drought are felt more in relation to the social system. These results suggest that perceptions of risk to nature from the hazards is worth considering for acceptance, in addition to the appreciation of ecosystem services from the NbS.

Connectedness to place is significant across the three sites and particularly strong for Catterline $(\rho=0.465, p<0.01)$. A related item on the surveys in Catterline, "landslides are a threat to our history and culture," is also strongly correlated with behavioral acceptance at $\rho=0.480(p<0.01)$. In regression models using attitudinal acceptance factors and risk, nature, and place variables, connectedness to place is one of only three variables retained in two of the sites (along with good and satisfied and past impacts) (Table 6). It is not retained in the Catterline model despite its strong correlation, likely due to also having strong correlations with the remaining predictors $(\rho=0.435, p<0.01$ with good and satisfied and $\rho=0.443, p<0.01$ with risk perception). The models explain $27.7 \%$ (Catterline), $31.7 \%$ (Puruvesi), and $37.7 \%$ (Spercheios) of the variance in behavioral acceptance in each of the three sites and all three models are significant at $p<0.01$ (Catterline $\mathrm{F}(2,65)=$ $12.09, p=0.000 ; \mathrm{R}^{2}=0.277$; Puruvesi $\mathrm{F}(5,180)=16.22, p=0.000 ; \mathrm{R}^{2}$ $=0.317$; Spercheios F $\left.(4,82)=11.76, p=0.000 ; \mathrm{R}^{2}=0.377\right)$.

Risk perception is the strongest predictor of behavioral acceptance for any of the sites, at $\beta=0.382(p<0.01)$ in Catterline. In Puruvesi, items related to all three themes of risk, nature and place are significant predictors, as well as the attitudinal factor benefits over costs. There, experience of past impacts as well as the perceived potential for future impacts are unique significant predictors $(\beta=0.162, p<0.05 ; \beta=0.173, p<0.05)$. In Spercheios, attitudes emerge as being particularly important for predicting behavioral acceptance (trust in implementers $\beta=0.263, p<0.01$; good and satisfied $\beta=0.241, p<0.05)$, along with past impacts $(\beta=$ $0.287, p<0.01)$ and connectedness to place $(\beta=0.297, p<0.01)$. This finding for Spercheios suggests that strategies aimed at increasing positive attitudes towards the $\mathrm{NbS}$ may translate into increased public engagement. Appealing to public pride in place is warranted, a theme returned to in the discussion.

Also noteworthy is the absence of risk intolerance from any of the models. Its lack of explanatory ability beyond risk perception and impact scales may be in part due to low variation of skewed right responses for its items (generally risk of listed impacts was not at all tolerated by respondents; see Supplementary Table S6 for descriptive statistics of risk, nature, and place variables). Using simple linear regression, we found that neither age nor gender is a significant predictor of behavioral acceptance in the sites.

\section{Do Attitudes Towards NbS Act as Moderating Variables?}

We assessed attitudes as moderating the influence of risk, nature, and place variables on behavioral acceptance in each site. After testing for moderation effects of the two attitudinal factors per site, we found one significantly moderating variable $(p<0.05)$ in Catterline (good and satisfied) and one in Puruvesi (trust in implementers) (Figure 5). In Catterline, the factor good and satisfied moderates variables related to all three themes of risk, nature and place-future impacts, commitment to nature, responsibility to nature and connectedness to place. As "good and satisfied" attitudes towards the NbS increase, each of these variables are significantly more predictive of behavior (full output in Supplementary Table S7). This suggests that strategies for increasing behavioral acceptance based on the public's perception of future impacts and relation with nature and place may only be successful if they are also able to improve these attitudes towards the NbS.

In Puruvesi, the attitudinal factor trust in implementers significantly reduces the effect of risk perception on behavioral acceptance $\left[\mathrm{F}(3,179)=8.58, p=0.000 ; \mathrm{R}^{2}=0.126 ; \mathrm{X}^{\star} \mathrm{M} b=\right.$ $-0.146, p=0.018]$. Significant relations between risk perception and public trust are well-established, albeit contextual (Slovic 1999; Viklund 2003; Siegrist et al., 2005; Siegrist 2019), but less so as 

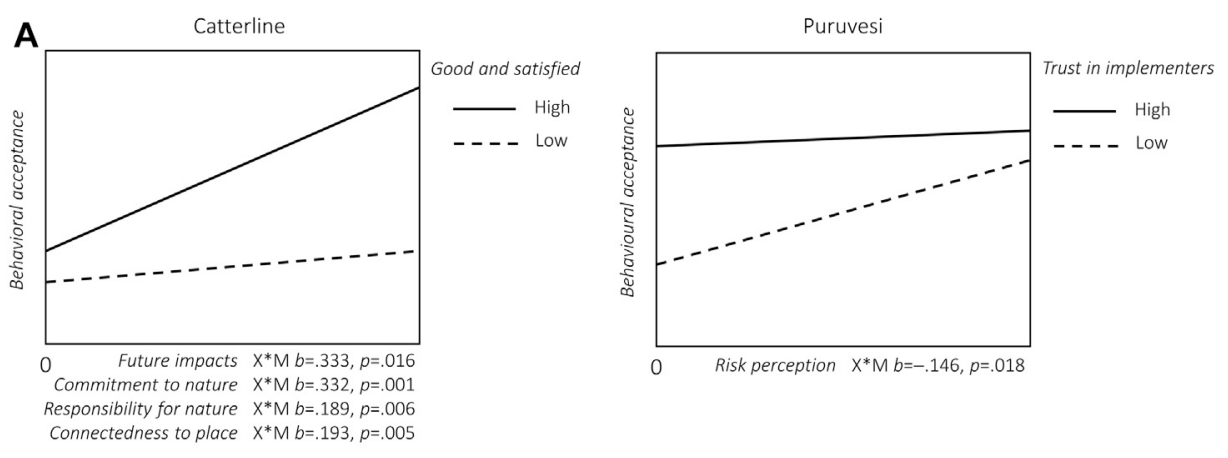

B

\begin{tabular}{lccccccc}
\hline \multicolumn{1}{c}{ Model } & Predictor & Moderating attitudinal factor & $\mathrm{R}^{2}$ & $F$ & $\mathrm{P}$ & $\mathrm{df1}$ & $\mathrm{df2}$ \\
\hline Catterline_1 & Future Impacts & good and satisfied & .294 & 8.61 & .000 & 3 & 62 \\
\hline Catterline_2 & Commitment to nature & good and satisfied & .343 & 10.80 & .000 & 3 & 62 \\
\hline Catterline_3 & Responsibility for nature & good and satisfied & .258 & 6.97 & .000 & 3 & 60 \\
\hline Catterline_4 & Connectedness to place & good and satisfied & .277 & 7.92 & 000 & 3 & 62 \\
\hline Puruvesi_1 & Risk perception & trust in implementers & .126 & 8.58 & .000 & 3 & 179
\end{tabular}

FIGURE 5 | Schematic representations of statistically significant $(p<0.05)$ moderating attitudinal acceptance factors in Catterline and Puruvesi (A) and model statistics (B). These factors (M) moderate relations between the risk, nature, and place predictor survey variables $(X)$ and behavioral acceptance. For example, in Puruvesi there is a significant positive relation between risk perception and behavioral acceptance, but this relation is significantly stronger when respondents' scores on the attitudinal factors trust in implementers is low. These are schematic representations of relations. Further statistical output and graphs are provided under Supplementary Table S7.

interacting variables for risk management demand and corresponding behavior (Bronfman et al., 2008). One explanation for our finding is that residents who do not perceive the implementing authorities as capable of risk reduction (low trust) are more motivated by perceived risk and a desire to reduce it through engagement with the $\mathrm{NbS}$. This is supported by many survey comments suggesting alternative measures to reduce eutrophication, including: reducing variation in water level, implementing and monitoring wastewater regulation, banning fertilizers, and supporting beaver dams (see full survey comments in Supplementary Table S8). The finding suggests that risk framing will not increase acceptance of $\mathrm{NbS}$ without parallel gains in trust-both in the implementers and (confidence) in the effectiveness of the $\mathrm{NbS}$ (the item " $\mathrm{NbS}$ will reduce risk in the future" received the lowest standardized average response score in Puruvesi of all attitudinal acceptance items at 0.56/1; Figure 4).

\section{What Other Survey Variables Predict Behavioral Acceptance?}

As expected, when considering all survey variables the regression models increase in explanatory power. An item to assess the perceived social norm of risk intolerance-"other residents believe risk must be reduced"-in Spercheios emerges as the strongest predictor for any site at $\beta=0.487(p<0.01)$ (Table 7).

Considering all survey variables as independent variables, multiple regression models explain 51.9\% (Catterline), $41.1 \%$ (Puruvesi), and 46.7\% (Spercheios) of the variance in behavioral acceptance in each of the three sites and all three models are significant at $p<0.01$. (Catterline $F(4,48)=$ $11.86, p=0.000 ; \mathrm{R}^{2}=0.519$; Puruvesi $\mathrm{F}(6,181)=20.33, p=0.000$; $\mathrm{R}^{2}=0.411 ;$ Spercheios $\left.\mathrm{F}(2,79)=33.76, p=0.000 ; \mathrm{R}^{2}=0.467\right)$.

Both connectedness to place $(\beta=0.281, p<0.05)$ and threat to history and culture $(\beta=0.251, p<0.05)$ are significant predictors in
Catterline. This supports prior findings of individuals' relation to place for acceptance of NbS measures (Buijs 2009; Bihari and Ryan 2012; Roca and Villares 2012; Brink and Wamsler 2019) while also demonstrating that behavioral acceptance can be uniquely motivated by both a connection to place and perceived threat to that connection.

In Catterline, past supportive behavior of $\mathrm{NbS}$ was the strongest predictor of intention to support the measures $(\beta=$ $0.363, p<0.01$ ). This indicates that targeting residents who have already engaged will likely see the greatest uptake. Perhaps more importantly, having residents actively support the measures in some way may lead to further engagement and foster a sense of responsibility for risk reduction (this had a correlation of $\rho=$ $0.445, p<0.01$ ) with behavior).

The importance of perceived cost for attitudinal acceptance in Puruvesi was highlighted as also important for behavioral acceptance $(\beta=-0.235, p<0.01)$, along with past and future impacts $(\beta=0.151, p<0.05 ; \beta=0.168, p<0.05)$.

\section{DISCUSSION}

Shared findings across the sites lead to three key recommendations to increase public acceptance of rural, project based NbS for risk reduction. The recommendations, along with corresponding relevant findings, are first listed below. Strategies and site-specific results related to the key themes are then provided in more detail.

1) Demonstrating the effectiveness of NbS for risk reduction should be prioritized and linked to building trust.

There is skepticism among the public regarding the effectiveness of NbS. Trust in implementers is consistently an 
important factor for defining attitudes towards $\mathrm{NbS}$ and there is a high public willingness to actively engage.

2) The public's sense of place, despite being highly contextdependent, should be considered within $\mathrm{NbS}$ projects for their successful uptake.

Public connectedness to place is tied to the importance of the beauty, reputation, history, and culture of the sites and is related to behavioral acceptance.

3) In line with the benefits provided by NbS, both perceptions of risk and nature, as well as their interactions, are important for acceptance.

Perceptions of nature are consistently associated with attitudinal and behavioral acceptance across the sites. Perceived risk and particularly the threat of multiple future impacts is an important predictor of behavioral acceptance.

TABLE 7 | Multiple linear regression model results $(\mathbf{A})$ and standardised beta $(\beta)$ coefficients (B) using attitudinal factor scores and risk, nature, and place survey variables as independent variables and behavioral acceptance scores as the dependent variable in each study site.

\begin{tabular}{lccccc} 
Panel A & \multicolumn{7}{c}{} & \\
\hline Model & $\mathbf{R}^{\mathbf{2}}$ & Adj. $\mathbf{R}^{\mathbf{2}}$ & $\boldsymbol{F}$ & $\mathbf{d f}$ & $\mathbf{D W}$ \\
\hline Catterline & 0.519 & 0.475 & $11.86^{\mathrm{a}}$ & 48 & 1.98 \\
Puruvesi & 0.411 & 0.390 & $20.33^{\mathrm{a}}$ & 181 & 1.94 \\
Spercheios & 0.467 & 0.453 & $33.764^{\mathrm{a}}$ & 79 & 1.57
\end{tabular}

Panel B

\begin{tabular}{llll}
\hline Model & & \\
& Theme & Predictors & $\beta$ \\
\hline
\end{tabular}

Catterline

$\begin{array}{lll}\text { Acceptance } & \begin{array}{l}\text { Past acceptance (sum of past } \\ \text { actions) }\end{array} & 0.363^{\mathrm{a}} \\ \text { Place } & \begin{array}{l}\text { Connectedness to place } \\ \text { Risk }\end{array} & 0.281^{\mathrm{b}} \\ \text { Risk } & \begin{array}{l}\text { Future impacts (sum) } \\ \text { "Landslides a threat to history }\end{array} & 0.267^{\mathrm{b}} \\ & 0.251^{\mathrm{b}} \\ & \text { and culture" } & \end{array}$

Puruvesi

\begin{tabular}{|c|c|c|}
\hline Cost & "Financial cost too great" & $-0.235^{\mathrm{a}}$ \\
\hline Connectedness to place/ & "Enjoy spending my free time at & $0.209^{a}$ \\
\hline Nature & Commitment to nature & $0.189^{a}$ \\
\hline Responsibility & $\begin{array}{l}\text { "Feel responsible for risk } \\
\text { reduction" }\end{array}$ & $0.177^{a}$ \\
\hline & Future impacts (sum) & $0.168^{b}$ \\
\hline & Past impacts (sum) & $0.151^{b}$ \\
\hline
\end{tabular}

Spercheios

Risk intolerance (social norm)

Connectedness to place/

"Other residents believe risk

$0.581^{a}$

Identity

must be reduced"

"Sense of who I am tied to $\quad 0.275^{\mathrm{a}}$

Spercheios"
Commonalities across the sites suggest that these general recommendations are warranted, while site-specific findings must also be considered for acceptance within the OPERANDUM project and taken up in similar contexts (Figure 6).

\section{Key Themes and Recommendations for Increasing Public Acceptance}

\section{Effectiveness of $\mathrm{NbS}$ and Trust in Implementers for Public Acceptance}

We found high public demand for evidence of NbS effectiveness for risk reduction. While most respondents believe risk can be reduced and the NbS will have reasonable success, a range of attitudes between cautious optimism and outright skepticism were expressed. Results suggest that the surveys were conducted at a crucial time in the project lifespan in which most residents have cautious positive perceptions. This presents an opportunity to improve acceptance but also a risk of not fulfilling expectations.

Skepticism of NbS effectiveness is likely to be related to both $\mathrm{NbS}$ characteristics and broader context. Potential drivers of hesitant attitudes regarding effectiveness include the complexity and novelty of NbS (Schernewski et al., 2018; Seddon et al., 2020), their effects often being less visible to the public (e.g., rainwater absorption in Catterline and Puruvesi) (Duan et al., 2018; Miller and Montalto 2019), and their duration in implementation with a time lag for effectiveness (e.g., dependence on plant growth) (Kabisch et al., 2016; Shah et al., 2020; Anderson and Renaud 2021). Contextual characteristics such as the history of hazard events in the area, climate change and increasing impacts despite the measures, and zero-risk bias mean that managing NbS expectations is crucial. Therefore, adapting to risk, rather than solely mitigating it, should be a priority of NbS projects and clearly communicated to the public.

Ongoing efforts at collecting evidence of $\mathrm{NbS}$ effectiveness are well-positioned to increase public acceptance (Davis and Naumann 2017; Faivre et al., 2018; Chausson et al., 2020). However, perhaps the most powerful way to provide such evidence is through participatory citizen science initiatives in which residents can see for themselves the positive results of the $\mathrm{NbS}$ (Holstead et al., 2017) — not just risk reduction but also, e.g., biodiversity gains (Davenport et al., 2010; Pueyo-Ros et al., 2019). Findings show a very high willingness to actively engage in the $\mathrm{NbS}$ projects. Resources should be devoted to capacity building and involvement in implementation and monitoring, where appropriate. There is a discrepancy in public willingness to engage and the ability of relevant projects to capitalize on this, particularly for monitoring (Doswald et al., 2014; Puskás et al., 2021).

Although the evidence base for NbS is increasing, there is still substantial work to be done in this regard (Doswald et al., 2014; Kabisch et al., 2016; Davis and Naumann 2017; Chausson et al., 2020). Until NbS are well-established and there exists ample evidence of their contextual effectiveness, trust in implementers as a consistent attitudinal determinant of acceptance will be even more heavily relied on and must be maintained and/or strengthened (Howgate and Kenyon 2009). Trust-building should be a continuous priority, since it can be hard to gain but easy to lose in contexts of risk (Slovic 1999). 


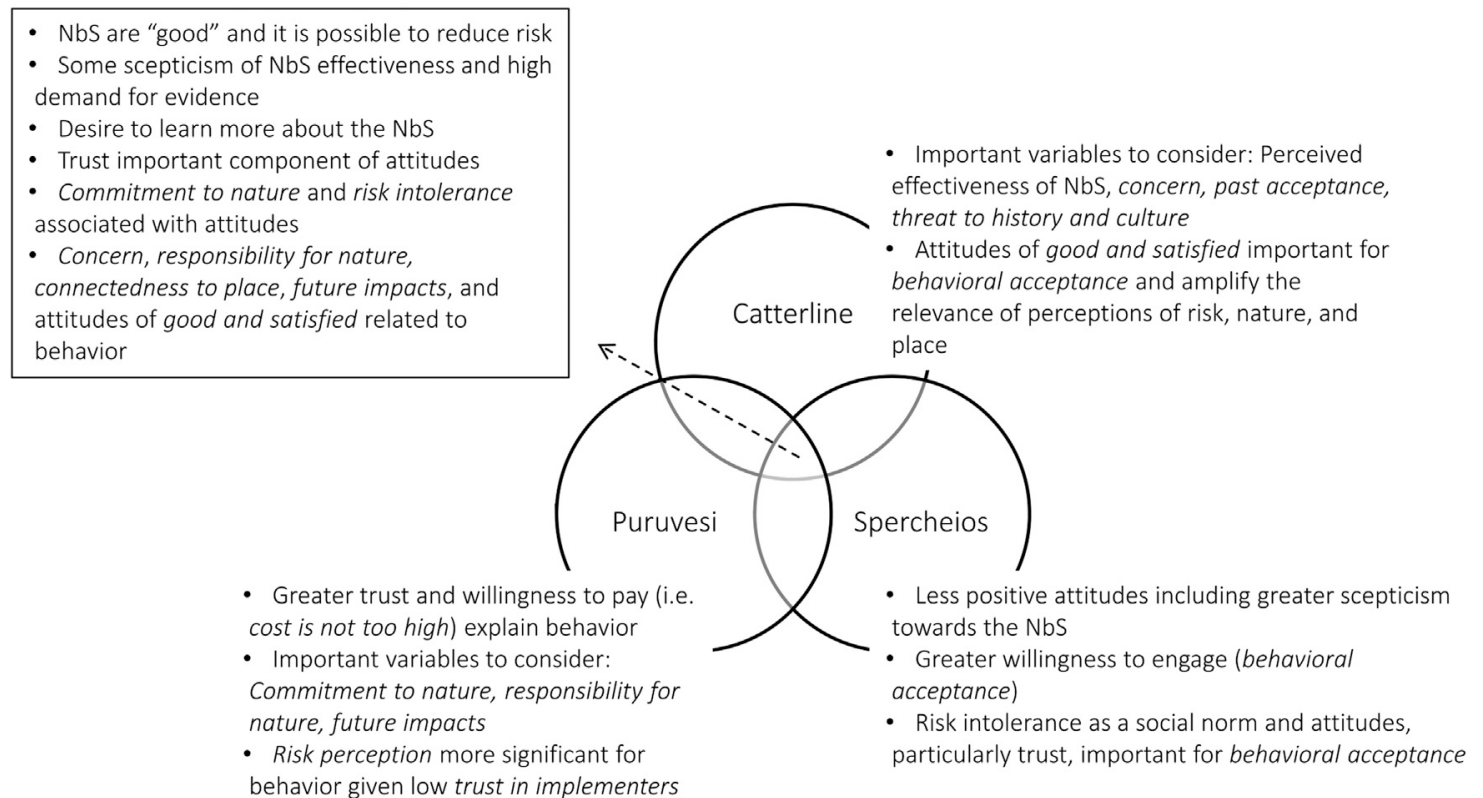

FIGURE 6 | Venn diagram of main findings shared across the study sites and specific findings within each site.

\section{Connectedness to Place for Public Acceptance}

In Puruvesi, the strong connectedness to place and the many comments regarding the importance of the reputation of Puruvesi are linked to the $\mathrm{NbS}$ and can be leveraged for improving acceptance (Supplementary Table S8). As one resident wrote, "If eutrophication is not controlled, Puruvesi's reputation as Finland's cleanest lake may have been lost. People may also lose hope that eutrophication could be brought under control and stop doing their part for control measures" (P140). Past research suggests that if $\mathrm{NbS}$ are able to enhance highly-valued local natural features, they are more likely to attain public support (Schmidt et al., 2014; Brink and Wamsler 2019). Conveying the importance of the NbS work, not only for improving lake quality but also for the sake of Puruvesi in its context as a highly respected Finnish lake, could be well-received by the public. This act of both localizing the issue and zooming out to the wider implications of $\mathrm{NbS}$ efforts will likely be more relevant and motivating for the residents (Buijs 2009; Groot and Groot 2009; Bihari and Ryan 2012; Goeldner-Gianella et al., 2015). Connecting Puruvesi's reputation with eutrophication and its impacts, it may be possible to appeal to the public's pride in- and sense of responsibility for-the natural area.

Connectedness to place was also strongly associated with behavior in Catterline. A related variable, "perceived threat to history and culture" was strongly correlated with behavioral acceptance and also with the general risk intolerance item of "risk must be reduced" ( $\rho=0.566, p<0.05)$. This is in line with Buijs (2009), who found that a threat to the perceived historical and cultural setting diminished support for $\mathrm{NbS}$ in the context of river restoration. Emphasizing landslides as a threat to place and community, as defined by cultural elements and practices, will likely resonate with residents. For example, amplifying the voices of long-time residents of Catterline in the form of narrative histories of landslide risk in relation to culture could increase knowledge on the issue and promote its position as a communal threat. Crucially, any such efforts must causally link the $\mathrm{NbS}$ as an effective actionable solution to the threat to avoid promoting a sense of despair or inevitability (O'Neill and Nicholson-Cole 2009).

Also in Spercheios, connectedness to place was related to acceptance, likely due to regional pride and rural identity. Providing tangible economic benefits in the form of increased tourism or otherwise may improve acceptance of the $\mathrm{NbS}$ (Kenyon 2007; Davenport et al., 2010; Roca and Villares 2012). However, this must be approached carefully since not everyone benefits from tourism and a sense of inequity of benefits could be fostered, reducing acceptance (Beery 2018; Otto et al., 2018).

The strongest correlate of behavioral acceptance in Spercheios was the item "other residents believe risk must be reduced". The perceived social norm of risk reduction is linked to both place and responsibility. Further research should aim at determining whether this is more a function of a moral norm (i.e., "we should act") or a social dilemma (i.e., "I won't act unless others do"), although survey results point more strongly to the former. This finding suggests that strategies for increasing acceptance may be successful by demonstrating that other residents are 1) concerned about natural hazard risk and 2) supporting the $\mathrm{NbS}$ work as a result. Testimonials, for example of well-respected and long-standing community members affected by flooding who support the $\mathrm{NbS}$, could be trialed along with publicizing strong attendance at $\mathrm{NbS}$-related activities. Also, pictures of engaged community members or "engagement days" in which locals come out to support the $\mathrm{NbS}$ together could be piloted.

\section{Perceptions of Risk and Nature for Public Acceptance}

The consistent significant relations between nature-related variables and acceptance reflect the importance of $\mathrm{NbS}$ co-benefits and how these measures are framed to the public, i.e., as more than just interventions to reduce risk. One quotation from Catterline captures 
the recognition of $\mathrm{NbS}$ as multi-functional, but primarily intended for risk reduction: "I think if the measures are as natural as possible this is best for [the] environment and residents. If [they were] manmade prevention methods, I'd be less inclined to support them unless guaranteed benefits" (C9). Anecdotal evidence from the site also points towards peaks in public engagement in the aftermath of landslides that wanes over time, underscoring temporal fluctuations in the salience of risk and impacts in relation to engagement.

The importance of perceived cost for attitudinal acceptance in Puruvesi was highlighted as also important for behavioral acceptance, together with the number of past- and future impacts experienced by respondents. Many comments from respondents in Puruvesi reflect varying degrees of perceived severity of the issue of eutrophication (Supplementary Table S8), for example: “...Is there now a fuss about something that can be influenced, when in reality the effect is non-existent?" (P96); "Blue-green algal blooms occur in small and predictable areas" (P193); "There have hardly been any of them at my cottage beach" (P205). In this case it seems that the unequal spatial distribution and ephemerality of impacts play an important role in determining whether residents believe the ongoing $\mathrm{NbS}$ efforts against eutrophication are worth the resources invested. This is supported by an item for general risk intolerance "risk must be reduced" showing a correlation of $\rho=0.327(p<0.01)$ with the factor benefits outweigh costs in Puruvesi. The relatively invisible causal mechanisms behind eutrophication (e.g., rainwater runoff vs. infiltration), may exacerbate this effect. Past research on infrequent hazards and climate change also shows that when threats are perceived as distant in space and time there is less willingness to take action against them (Rambonilaza et al., 2016; Everett et al., 2018; Brink and Wamsler 2019).

The importance of proving the effectiveness of $\mathrm{NbS}$ (Miller and Montalto 2019; Chausson et al., 2020), as well as its cost-effectiveness (Davis and Naumann 2017; Faivre et al., 2017; Reguero et al., 2018), is reiterated here. Strategies to demonstrate the negative effects of eutrophication to a greater public than those who are affected by any one algal bloom event are worth considering. Water clarity is a simple and easily relatable indicator of water quality and therefore may be useful for developing persuasive and memorable communication material. It also ties into the importance of the reputation of Puruvesi in Finland as a benchmark for water quality and the strong connectedness to place.

Perceptions of risk are motivators for acceptance and the primary $\mathrm{NbS}$ aim of risk reduction should not be detracted from, despite cobenefits being potential additional motivators for $\mathrm{NbS}$ acceptance. Nevertheless, natural co-benefits of the $\mathrm{NbS}$ are important for increasing acceptance among the wider community and for outreach to residents who may benefit less from risk reduction.

\section{Limitations and Future Outlook}

Our survey variables reflect the characteristic of this study as interdisciplinary and exploratory. Many of the variables most strongly related to acceptance are in line with Protection Motivation Theory (Rogers 1975), while the importance of social norms for risk reduction in Spercheios, for example, supports more thorough inclusion of variables and testing also for the Theory of Planned Behavior (Ajzen 1991). Further research should systematically test these theories and others (Kuhlicke et al., 2020) including well-established variables such as self-efficacy for public acceptance of $\mathrm{NbS}$, while also incorporating our findings regarding the importance of nature and place-based perceptions. Although the behavioral acceptance scale was highly reliable in all sites (high validity supported by respondents with high acceptance providing their contact information significantly more than respondents with low acceptance; Mann-Whitney $U p<0.05)$, research is also needed to advance scale(s) for assessing attitudinal acceptance of $\mathrm{NbS}$.

Other variables, such as awareness and understanding of the measures, although found to be important for public perception of $\mathrm{NbS}$ in recent literature reviews (Han and Kuhlicke 2019; Anderson and Renaud 2021), were excluded from this research. The surveys were self-administered, and we aimed to prevent respondents from feeling "tested" on their knowledge. The OPERANDUM project was ongoing at the time of the surveys and these were carefully designed to not detract from public acceptance by eroding trust or creating stakeholder fatigue. Since our study sites were rural, exposed to hydro-meteorological risk, and the projects externally led, the variables may not apply to other NbS contexts and should be further tested where appropriate. It is possible that connectedness to place is more associated with acceptance where deeply rooted rural identities are prevalent (indeed, segmenting Spercheios data supports this hypothesis) (Buijs 2009). Beyond the internal variables we tested for, research should continue to support the success of $\mathrm{NbS}$ through a deeper understanding of the wide range of external considerations (e.g., financial and governmental) (Nesshöver et al., 2017; Wamsler et al., 2019; Seddon et al., 2020), as well as social contexts and issues of practicality that can also determine engagement (Blake 1999). Future public perceptions of $\mathrm{NbS}$ depend on their overall success.

We recognize the limitations of our non-randomized single point sampling approach. Additionally, the response rate for Puruvesi was quite low at $10.3 \%$. It is likely that these results show higher acceptance than the population, given that the motivation to complete the survey may represent a certain level of acceptance. However, opposition is also a powerful motivator and it may be that polarized views were over represented, since the written in comments on the surveys also expressed complaints about the NbS work. The broad range of comments and Likert responses bolsters confidence in the surveys having captured more than a specific subsection of the population. Our findings provide baseline evidence for developing strategies to increase public acceptance of $\mathrm{NbS}$. However, all such efforts should first be piloted and segment the public as much as possible. Further segmentation of results presented here are not reported due to space constraints. Our use of multiple statistical tests combined with expert knowledge and survey comments increases confidence in the interpretation and recommendations. However, questions around contextual objectives such as "Should we aim to improve the most negative attitudes towards NbS?" or "Do we need to ensure at least limited public collaboration?" are crucial considerations for further actionable research.

Experiments to test the effects of risk, nature and place framings on acceptance, for example, would help establish causal, rather than just correlate, relations and advance the field (Kuhlicke et al., 2020). Moreover, these designs could overcome the current limitation of assessing behavioral intention rather than actual engagement (Sheeran 2002). The 
importance of perceptions of nature and benefits versus costs supports the systematic study of perceived ecosystem services of $\mathrm{NbS}$ and their relation to public acceptance, including the primary aim of risk reduction (Doswald et al., 2014; Kabisch et al., 2016). Follow-up research to examine these interactions more closely is currently being carried out by the lead authors.

\section{CONCLUSION}

Understanding what drives public acceptance of NbS for risk reduction is essential for the success of NbS projects and a first step towards their continued uptake in Europe and beyond. Additionally, public outreach should frame $\mathrm{NbS}$ not based on what is assumed to be important to public stakeholders, but rather what is evidenced as being highly valued. Our findings support the importance of perceptions of nature and place in contexts of $\mathrm{NbS}$, along with effective risk reduction.

Despite current support, actively investing in campaigns to improve attitudes and behavior towards $\mathrm{NbS}$ rather than assuming continued public acceptance is crucial. Providing benefits through effective $\mathrm{NbS}$ is essential, but the burden of proof through evidence is a subsequent hurdle, particularly in the context of increasing risk due to climate change. Our findings not only have immediate practical implications for stakeholder engagement within OPERANDUM study sites but also broader lessons for European and global NbS.

\section{DATA AVAILABILITY STATEMENT}

The original contributions presented in the study are included in the article/Supplementary Material, further inquiries can be directed to the corresponding author.

\section{REFERENCES}

Abdi, H. (2003). "Factor Rotations in Factor Analyses," in Encyclopedia of Social Sciences Research Methods. Editors M. Lewis-Beck, A. Bryman, and T. Futing (Thousand Oaks, California: SAGE).

Ajzen, I. (1991). The Theory of Planned Behavior. Organizational Behav. Hum. Decis. Process. 50, 179-211. doi:10.1016/0749-5978(91)90020-t

Anderson, C. C., and Renaud, F. G. (2021). A Review of Public Acceptance of NatureBased Solutions: The 'why', 'When', and 'how' of success for Disaster Risk Reduction Measures. Ambio. 50, 1552-1573. doi:10.1007/s13280-021-01502-4

Baird, B. N. R. (1986). Tolerance for Environmental Health Risks: The Influence of Knowledge, Benefits, Voluntariness, and Environmental Attitudes. Risk Anal. 6 (4), 425-435. doi:10.1111/j.1539-6924.1986.tb00955.x

Bark, R. H., Martin-Ortega, J., and Waylen, K. A. (2021). Stakeholders' Views on Natural Flood Management: Implications for the Nature-Based Solutions Paradigm Shift? Environ. Sci. Pol. 115, 91-98. doi:10.1016/j.envsci.2020.10.018

Barthélémy, C., and Armani, G. (2015). A Comparison of Social Processes at Three Sites of the French Rhône River Subjected to Ecological Restoration. Freshw. Biol. 60 (6), 1208-1220. doi:10.1111/fwb.12531

Beery, T. (2018). Engaging the Private Homeowner: Linking Climate Change and Green Stormwater Infrastructure. Sustainability. 10 (12), 4791. doi:10.3390/su10124791

Begg, C., Luther, J., Kuhlicke, C., and Steinführer, A. (2011). Participation in Central European Flood Risk Management: Social Capacity Building in Practice.

\section{ETHICS STATEMENT}

This research was reviewed and approved by the University of Glasgow College of Social Sciences Ethics Committee and follows the GDPR. The participants provided their written informed consent to participate in this study.

\section{AUTHOR CONTRIBUTIONS}

Conceptualization, CA and FR; data collection, CA, KM, AG-O, $\mathrm{EP}, \mathrm{KS}, \mathrm{ML}, \mathrm{DP}$, and MS; investigation, CA; data curation, CA; writing-original draft preparation, $\mathrm{CA}$; writing-review and editing, CA, FR, SH, KM, AG-O, CT, EP, KS, ML, and DP; supervision, FR, $\mathrm{SH}$; project administration, FR, KM, AG-O, CT, EP, KS, ML, DP, and MS; funding acquisition, FR. All authors have read and agreed to the published version of the manuscript.

\section{FUNDING}

The contribution of CA was supported by a University of Glasgow College of Social Sciences PhD Scholarship. This work was supported by the European Union's (EU) Horizon 2020 research and innovation program. It was funded by and carried out within the framework of the OPERANDUM (OPEn-air laboRAtories for Nature baseD solUtions to Manage hydro-meteo risks) project (Grant No. 776848).

\section{SUPPLEMENTARY MATERIAL}

The Supplementary Material for this article can be found online at: https://www.frontiersin.org/articles/10.3389/fenvs.2021.678938/ full\#supplementary-material

CapHaz-Net WP9 Report. Leipzig, Germany: Helmholtz Centre for Environmental Research - UFZ.

Begg, C., Callsen, I., Kuhlicke, C., and Kelman, I. (2018). The Role of Local Stakeholder Participation in Flood Defence Decisions in the United Kingdom and Germany. J. Flood Risk Management. 11 (2), 180-190. doi:10.1111/jfr3.12305

Bernaards, C. A., and Sijtsma, K. (2000). Influence of Imputation and EM Methods on Factor Analysis when Item Nonresponse in Questionnaire Data is Nonignorable. Multivariate Behav. Res. 35 (3), 321-364. doi:10.1207/ S15327906MBR3503 03

Bihari, M., and Ryan, R. (2012). Influence of Social Capital on Community Preparedness for Wildfires. Landscape Urban Plann. 106 (3), 253-261. doi:10.1016/j.landurbplan.2012.03.011

Birkmann, J., and von Teichman, K. (2010). Integrating Disaster Risk Reduction and Climate Change Adaptation: Key Challenges-Scales, Knowledge, and Norms. Sustain. Sci. 5 (2), 171-184. doi:10.1007/s11625-010-0108-y

Biswas, S. R., Mallik, A. U., Choudhury, J. K., and Nishat, A. (2009). A Unified Framework for the Restoration of Southeast Asian Mangroves-Bridging Ecology, Society and Economics. Wetlands Ecol. Manage. 17 (4), 365-383. doi:10.1007/s11273-008-9113-7

Blake, J. (1999). Overcoming the 'Value-Action Gap' in Environmental Policy: Tensions Between National Policy and Local Experience. Local Environ. 4 (3), 257-278. doi:10.1080/13549839908725599

Boateng, G. O., Neilands, T. B., Frongillo, E. A., Melgar-Quiñonez, H. R., Young, S. L., and Young, S. L. (2018). Best Practices for Developing and Validating Scales 
for Health, Social, and Behavioral Research: A Primer. Front. Public Health. 6, 149. doi:10.3389/fpubh.2018.00149

Böhm, G., and Hans-Rüdiger, P. (2000). Action Tendencies and Characteristics of Environmental Risks. Acta Psychologica. 104 (3), 317-337. doi:10.1016/s00016918(00)00035-4

Borsboom, D. (2005). Measuring the Mind. Conceptual Issues in Contemporary Psychometrics. Cambridge: Cambridge University Press. doi:10.1017/ cbo9780511490026

Briggs, S. R., and Cheek, J. M. (1986). The Role of Factor Analysis in the Development and Evaluation of Personality Scales. J. Personal. 54 (1), 106-148. doi:10.1111/j.1467-6494.1986.tb00391.x

Brink, E., and Wamsler, C. (2019). Citizen Engagement in Climate Adaptation Surveyed: The Role of Values, Worldviews, Gender and Place. J. Clean. Prod. 209, 1342-1353. doi:10.1016/j.jclepro.2018.10.164

Bronfman, N. C., Vázquez, E. L., Gutiérrez, V. V., and Cifuentes, L. A. (2008). Trust, Acceptance and Knowledge of Technological and Environmental Hazards in Chile. J. Risk Res. 11 (6), 755-773. doi:10.1080/13669870801967184

Bubeck, P., Botzen, W. J. W., Suu, L. T. T., and Aerts, J. C. J. H. (2012). Do flood Risk Perceptions Provide Useful Insights for Flood Risk Management? Findings From Central Vietnam. J. Flood Risk Manage. 5 (4), 295-302. doi:10.1111/ j.1753-318X.2012.01151.x

Bubeck, P., Kreibich, H., Penning-Rowsell, E. C., Botzen, W. J. W., de Moel, H., and Klijn, F. (2017). Explaining Differences in Flood Management Approaches in Europe and in the USA - a Comparative Analysis. J. Flood Risk Manage. 10 (4), 436-445. doi:10.1111/jfr3.12151

Buchecker, M., Menzel, S., and Home, R. (2013). How Much Does Participatory Flood Management Contribute to Stakeholders' Social Capacity Building? Empirical Findings Based on a Triangulation of Three Evaluation Approaches. Nat. Hazards Earth Syst. Sci. 13 (6), 1427-1444. doi:10.5194/ nhess-13-1427-2013

Buchecker, M., Ogasa, D. M., and Maidl, E. (2016). How Well Do the Wider Public Accept Integrated Flood Risk Management? an Empirical Study in Two Swiss Alpine Valleys. Environ. Sci. Pol. 55, 309-317. doi:10.1016/j.envsci.2015.07.021

Buijs, A. E. (2009). Public Support for River Restoration. A Mixed-Method Study into Local Residents' Support for and Framing of River Management and Ecological Restoration in the Dutch Floodplains. J. Environ. Manag. 90 (8), 2680-2689. doi:10.1016/j.jenvman.2009.02.006

Chambers, R. (1994). The Origins and Practice of Participatory Rural Appraisal. World Development. 22 (7), 953-969. doi:10.1016/0305-750x(94)90141-4

Chausson, A., Turner, B., Seddon, D., Chabaneix, N., Girardin, C. A. J., Kapos, V., et al. (2020). Mapping the Effectiveness of Nature-based Solutions for Climate Change Adaptation. Glob. Change Biol. 26, 6134-6155. doi:10.1111/gcb.15310

Chowdhury, M. R. (2003). The Impact of 'Greater Dhaka Flood Protection Project' (GDFPP) on Local Living Environment - the Attitude of the Floodplain Residents. Nat. Hazards. 29, 309-324. doi:10.1023/A:1024798931426

Cohen-Shacham, E., Walters, G., Janzen, C., and Maginnis, S. (2016). Nature-based Solutions to Address Global Societal Challenges. Gland, Switzerland: IUCN, 97.

Connop, S., Vandergert, P., Eisenberg, B., Collier, M. J., Nash, C., Clough, J., et al. (2016). Renaturing Cities Using a Regionally-Focused Biodiversity-Led Multifunctional Benefits Approach to Urban green Infrastructure. Environ. Sci. Pol. 62, 99-111. doi:10.1016/j.envsci.2016.01.013

Daly, D., Jodieri, R., McCarthy, S., Pygott, K., and Wright, M. (2015). Communication and Engagement in Local Flood Risk Management. London: CIRIA C, CIRIA-C-751.

Davenport, M. A., Bridges, C. A., Mangun, J. C., Carver, A. D., Williard, K. W. J., and Jones, E. O. (2010). Building Local Community Commitment to Wetlands Restoration: a Case Study of the Cache River Wetlands in Southern Illinois, USA. Environ. Manag. 45 (4), 711-722. doi:10.1007/s00267-010-9446-x

Davis, J. L., Le, B., and Coy, A. E. (2011). Building a Model of Commitment to the Natural Environment to Predict Ecological Behavior and Willingness to Sacrifice. J. Environ. Psychol. 31 (3), 257-265. doi:10.1016/j.jenvp.2011.01.004

Davis, M., and Naumann, S. (2017). "Making the Case for Sustainable Urban Drainage Systems as a Nature-Based Solution to Urban Flooding," in NatureBased Solutions to Climate Change Adaptation in Urban Areas. Editors N Kabisch, H Korn, J Stadler, and A Bonn (Cham: Springer International Publishing).

Ding, L., Ren, X., Gu, R., and Che, Y. (2019). Implementation of the "Sponge City" Development Plan in China: An Evaluation of Public Willingness to Pay for the
Life-Cycle Maintenance of its Facilities. Cities. 93, 13-30. doi:10.1016/ j.cities.2019.04.007

DiStefano, C., Zhu, M., and Mîndrilã, D. (2009). Understanding and Using Factor Scores: Considerations for the Applied Researcher. Pract. Assess. Res. Eval. 14, 20. doi:10.7275/da8t-4g52

Doswald, N., Munroe, R., Roe, D., Giuliani, A., Castelli, I., Stephens, J., et al. (2014). Effectiveness of Ecosystem-Based Approaches for Adaptation: Review of the Evidence-Base. Clim. Development. 6 (2), 185-201. doi:10.1080/ 17565529.2013.867247

Duan, J., Wang, Y., Fan, C., Xia, B., and de Groot, R. (2018). Perception of Urban Environmental Risks and the Effects of Urban Green Infrastructures (UGIs) on Human Well-Being in Four Public Green Spaces of Guangzhou, China. Environ. Manag. 62 (3), 500-517. doi:10.1007/s00267-018-1068-8

Euler, J., and Heldt, S. (2018). From Information to Participation and SelfOrganization: Visions for European River basin Management. Sci. Total Environ. 621, 905-914. doi:10.1016/j.scitotenv.2017.11.072

European Commission (2000). Directive 2000/60/EC of the European Parliament and of the Council of 23 October 2000 Establishing a Framework for Community Action in the Field of Water Policy. Official Journal Eur. Communities L. 327/1, 1-72.

European Commission (2021). Science for Environment Policy. Future Brief: The Solution Is in Nature. 24th ed. Luxembourg: Publications Office of the European Union.

Evans, A. J., Garrod, B., Firth, L. B., Hawkins, S. J., Morris-Webb, E. S., Goudge, H., et al. (2017). Stakeholder Priorities for Multi-Functional Coastal Defence Developments and Steps to Effective Implementation. Mar. Pol. 75, 143-155. doi:10.1016/j.marpol.2016.10.006

Everett, G., Lamond, J. E., Morzillo, A. T., Matsler, A. M., and Chan, F. K. S. (2018). Delivering Green Streets: an Exploration of Changing Perceptions and Behaviours over Time Around Bioswales in Portland, Oregon. J. Flood Risk Management. 11, S973-S985. doi:10.1111/jfr3.12225

Fabrigar, L. R., Wegener, D. T., MacCallum, R. C., and Strahan, E. J. (1999). Evaluating the Use of Exploratory Factor Analysis in Psychological Research. Psychol. Methods. 4 (3), 272-299. doi:10.1037//1082-989X.4.3.27210.1037/ 1082-989x.4.3.272

Faivre, N., Fritz, M., Freitas, T., de Boissezon, B., and Vandewoestijne, S. (2017). Nature-Based Solutions in the EU: Innovating with Nature to Address Social, Economic and Environmental Challenges. Environ. Res. 159, 509-518. doi:10.1016/j.envres.2017.08.032

Faivre, N., Sgobbi, A., Happaerts, S., Raynal, J., and Schmidt, L. (2018). Translating the Sendai Framework into Action: the EU Approach to Ecosystem-Based Disaster Risk Reduction. Int. J. Disaster Risk Reduction. 32, 4-10. doi:10.1016/ j.ijdrr.2017.12.015

Ferreira, V., Barreira, A., Loures, L., Antunes, D., and Panagopoulos, T. (2020). Stakeholders' Engagement on Nature-Based Solutions: A Systematic Literature Review. Sustainability. 12 (2), 640. doi:10.3390/su12020640

Finlay, P. J., and Fell, R. (1997). Landslides: Risk Perception and Acceptance. Can. Geotech. J. 34 (2), 169-188. doi:10.1139/t96-108

Fischhoff, B., Slovic, P., Lichtenstein, S., Read, S., and Combs, B. (1978). How Safe Is Safe Enough? A Psychometric Study of Attitudes towards Technological Risks and Benefits. Policy Sci. 9 (2), 127-152. doi:10.1007/bf00143739

Fordham, M., Tunstall, S., and Penning-Rowsell, E. C. (1991). Choice and Preference in the Thames Floodplain: the Beginnings of a Participatory Approach?. Landscape Urban Plann. 20 (1-3), 183-187. doi:10.1016/0169-2046(91)90109-y

Georghiou, K. (1996). Specific Management Plan for the Site Koilada Kai Ekvoles Spercheiou-Maliakos Kolpos (GR2440002). With Assistance of the Goulandris Natural History Museum-Greek Biotope/Wetland Centre. Thermi: University of Athens.

Gifford, R., and Comeau, L. A. (2011). Message Framing Influences Perceived Climate Change Competence, Engagement, and Behavioral Intentions. Glob. Environ. Change. 21 (4), 1301-1307. doi:10.1016/j.gloenvcha.2011.06.004

Giordano, R., Pluchinotta, I., Pagano, A., Scrieciu, A., and Nanu, F. (2020). Enhancing Nature-Based Solutions Acceptance through Stakeholders' Engagement in Co-benefits Identification and Trade-Offs Analysis. Sci. Total Environ. 713, 136552. doi:10.1016/j.scitotenv.2020.136552

Godschalk, D. R., Brody, S., and Burby, R. (2003). Public Participation in Natural Hazard Mitigation Policy Formation: Challenges for Comprehensive Planning. 
J. Environ. Plann. Management. 46 (5), 733-754. doi:10.1080/ 0964056032000138463

Goeldner-Gianella, L., Bertrand, F., Oiry, A., and Grancher, D. (2015). Depolderisation Policy against Coastal Flooding and Social Acceptability on the French Atlantic Coast: The Case of the Arcachon Bay. Ocean Coastal Management. 116, 98-107. doi:10.1016/ j.ocecoaman.2015.07.001

Gonzalez-Ollauri, A., and Mickovski, S. B. (2017). Shallow Landslides as Drivers for Slope Ecosystem Evolution and Biophysical Diversity. Landslides. 14 (5), 1699-1714. doi:10.1007/s10346-017-0822-y

Groot, M. de., and Groot, W. T. de. (2009). "Room for River" Measures and Public Visions in the Netherlands: A Survey on River Perceptions Among riverside Residents. Water Resour. Res. 45 (7), 1-11. doi:10.1029/2008WR007339

Han, S., and Kuhlicke, C. (2019). Reducing Hydro-Meteorological Risk by NatureBased Solutions: What Do We Know about People's Perceptions? Water 11 (12), 2599. doi:10.3390/w11122599

Hayes, A. F. (2017). Introduction to Mediation, Moderation, and Conditional Process Analysis: A Regression-Based Approach. New York, NY: Guilford publications.

Haynes, K., Barclay, J., and Pidgeon, N. (2008). Whose Reality Counts? Factors Affecting the Perception of Volcanic Risk. J. Volcanology Geothermal Res. 172 (3-4), 259-272. doi:10.1016/j.jvolgeores.2007.12.012

Heldt, S., Budryte, P., Ingensiep, H. W., Teichgräber, B., Schneider, U., and Denecke, M. (2016). Social Pitfalls for River Restoration: How Public Participation Uncovers Problems with Public Acceptance. Environ. Earth Sci. 75 (13), 1053. doi:10.1007/s12665-016-5787-y

Herringshaw, C. J., Thompson, J. R., and Stewart, T. W. (2010). Learning about Restoration of Urban Ecosystems: a Case Study Integrating Public Participation, Stormwater Management, and Ecological Research. Urban Ecosyst. 13 (4), 535-562. doi:10.1007/s11252-010-0134-7

Holstead, K. L., Kenyon, W., Rouillard, J. J., Hopkins, J., and Galán-Díaz, C. (2017). Natural Flood Management from the Farmer's Perspective: Criteria that Affect Uptake. J. Flood Risk Manage. 10 (2), 205-218. doi:10.1111/jfr3.12129

Homer, P. M., and Kahle, L. R. (1988). A Structural Equation Test of the ValueAttitude-Behavior Hierarchy. J. Personal. Soc. Psychol. 54, 638-646. doi:10.1037/0022-3514.54.4.638

Hopkins, T. S., Bailly, D., Elmgren, R., Glegg, G., Sandberg, A., and Støttrup, J. G. (2012). A Systems Approach Framework for the Transition to Sustainable Development: Potential Value Based on Coastal Experiments. EઐS. 17 (3), 39. doi:10.5751/ES-05266-170339

Howgate, O. R., and Kenyon, W. (2009). Community Cooperation With Natural Flood Management: a Case Study in the Scottish Borders. Area. 41 (3), 329-340. doi:10.1111/j.1475-4762.2008.00869.x

International Union for Conservation of Nature (2020). IUCN Global Standard for Nature-Based Solutions: A User-Friendly Framework for the Verification, Design and Scaling up of NbS. first edition. Gland, Switzerland: IUCN, International Union for Conservation of Nature.

Irvin, R. A., and Stansbury, J. (2004). Citizen Participation in Decision Making: is it Worth the Effort? Public Adm. Rev. 64 (1), 55-65. doi:10.1111/j.15406210.2004.00346.x

Jacobs, M. H., and Buijs, A. E. (2011). Understanding Stakeholders' Attitudes Toward Water Management Interventions: Role of Place Meanings. Water Resour. Res. 47 (1), W01503. doi:10.1029/2009WR008366

Jones, N., Clark, J. R. A., Panteli, M., Proikaki, M., and Dimitrakopoulos, P. G. (2012). Local Social Capital and the Acceptance of Protected Area Policies: an Empirical Study of Two Ramsar River delta Ecosystems in Northern Greece. J. Environ. Manag. 96 (1), 55-63. doi:10.1016/j.jenvman.2011.10.012

Jorgensen, B. S., and Stedman, R. C. (2001). Sense of Place as an Attitude: Lakeshore Owners Attitudes Toward Their Properties. J. Environ. Psychol. 21 (3), 233-248. doi:10.1006/jevp.2001.0226

Kabisch, N., Frantzeskaki, N., Pauleit, S., Naumann, S., Davis, M., Artmann, M., et al. (2016). Nature-based Solutions to Climate Change Mitigation and Adaptation in Urban Areas: Perspectives on Indicators, Knowledge Gaps, Barriers, and Opportunities for Action. Ecol. Soc. 21 (2), 39. doi:10.5751/es-08373-210239
Kenyon, W. (2007). Evaluating Flood Risk Management Options in Scotland: A Participant-Led Multi-Criteria Approach. Ecol. Econ. 64 (1), 70-81. doi:10.1016/j.ecolecon.2007.06.011

Koutrakis, E., Sapounidis, A., Marzetti, S., Marin, V., Roussel, S., Martino, S., et al. (2011). ICZM and Coastal Defence Perception by beach Users: Lessons from the Mediterranean Coastal Area. Ocean Coastal Management. 54 (11), 821-830. doi:10.1016/j.ocecoaman.2011.09.004

Kuhlicke, C., Seebauer, S., Hudson, P., Begg, C., Bubeck, P., Dittmer, C., et al. (2020). The Behavioral Turn in Flood Risk Management, its Assumptions and Potential Implications. WIREs Water. 7 (3). doi:10.1002/wat2.1418

La Tozier de Poterie, A., and Baudoin, M-A. (2015). From Yokohama to Sendai: Approaches to Participation in International Disaster Risk Reduction Frameworks. Int. J. Disaster Risk Sci. 6 (2), 128-139. doi:10.1007/s13753015-0053-6

Liere, K. D. V., Dunlap, R. E., and Dunlap, R. E. (1980). The Social Bases of Environmental Concern: A Review of Hypotheses, Explanations and Empirical Evidence. Public Opin. Q. 44 (2), 181-197. doi:10.1086/268583

Lijphart, A. (1975). II. The Comparable-Cases Strategy in Comparative Research. Comp. Polit. Stud. 8 (2), 158-177. doi:10.1177/001041407500800203

Macherera, M., and Chimbari, M. J. (2016). A Review of Studies on Community Based Early Warning Systems. J. Disaster Risk Stud. 8 (1), 1996-1421. doi:10.4102/jamba.v8i1.206

Maskrey, A. (1989). Disaster Mitigation: A Community Based Approach. Editor B. Pratt (Oxford: Development Guidelines), 3.

Maynard, W. S., Nealey, S. M., Hebert, J. A., and Lindell, M. K. (1976). Public Values Associated with Nuclear Waste Disposal. Report BNWL-1997 (UC-70). Washington: Batelle Memorial Institute, Human Affairs Research Centers. Seattle.

Mees, H. L. P., Driessen, P. P. J., and Runhaar, H. A. C. (2012). Exploring the Scope of Public and Private Responsibilities for Climate Adaptation. J. Environ. Pol. Plann. 14 (3), 305-330. doi:10.1080/1523908X.2012.707407

Miller, S. M., and Montalto, F. A. (2019). Stakeholder Perceptions of the Ecosystem Services provided by Green Infrastructure in New York City. Ecosystem Serv. 37, 100928. doi:10.1016/j.ecoser.2019.100928

Mills, M., van de Bunt, G. G., de Bruijn, J., and Bruijn, J. de. (2006). Comparative Research. Int. Sociol. 21 (5), 619-631. doi:10.1177/0268580906067833

Moser, S. C., and Dilling, Li. (2011). "Communicating Climate Change: Closing the Science-Action gap," in The Oxford Handbook of Climate Change and Society. Editors J S. Dryzek, R B. Norgaard, and D Schlosberg (Oxford: Oxford University Press), 161-174.

Naumann, S., and Kaphengst, T. (2015). Erfolgsfaktoren bei der Planung und Umsetzung naturbasierter Ansätze zum Klimaschutz und zur Anpassung an den Klimawandel. Ein kurzer Leitfaden. 24th ed. Bonn, Germany: Bundesamt für Naturschutz. (BfN-Skripten 406).

Nesshöver, C., Assmuth, T., Irvine, K. N., Rusch, G. M., Waylen, K. A., Delbaere, B., et al. (2017). The Science, Policy and Practice of Nature-Based Solutions: An Interdisciplinary Perspective. Sci. Total Environ. 579, 1215-1227. doi:10.1016/ j.scitotenv.2016.11.106

O’Neill, S., and Nicholson-Cole, S. (2009). "Fear Won't Do it". Sci. Commun. 30 (3), 355-379. doi:10.1177/1075547008329201

Otto, A., Hornberg, A., and Thieken, A. (2018). Local Controversies of Flood Risk Reduction Measures in Germany. An Explorative Overview and Recent Insights. J. Flood Risk Manage. 11, S382-S394. doi:10.1111/jfr3.12227

Penning-Rowsell, E. C., and Johnson, C. (2015). The Ebb and Flow of Power: British Flood Risk Management and the Politics of Scale. Geoforum. 62, 131-142. doi:10.1016/j.geoforum.2015.03.019

Peters, E., Slovic, P., Hibbard, J. H., and Tusler, M. (2006). Why Worry? Worry, Risk Perceptions, and Willingness to Act to Reduce Medical Errors. Health Psychol. 25 (2), 144-152. doi:10.1037/0278-6133.25.2.144

Pfadenhauer, J. (2001). Some Remarks on the Socio-Cultural Background of Restoration Ecology. Restor Ecol. 9 (2), 220-229. doi:10.1046/j.1526100x.2001.009002220.x

Przeworksi, A., and Teune, H. (1970). The Logic of Comparative Social Inquiry. Wiley-Interscience, 94. doi:10.2307/1958372 
Pueyo-Ros, J., Ribas, A., and Fraguell, R. M. (2019). A Cultural Approach to Wetlands Restoration to Assess its Public Acceptance. Restor Ecol. 27 (3), 626-637. doi:10.1111/rec.12896

Pugliese, F., Caroppi, G., Zingraff-Hamed, A., Lupp, G., and Giugni, M. (2020). Nature-Based Solutions (NBSs) Application for Hydro-Environment Enhancement. A Case Study of the Isar River (DE). Environ. Sci. Proc. 2 (1), 30. doi:10.3390/environsciproc2020002030

Puskás, N., Abunnasr, Y., and Naalbandian, S. (2021). Assessing Deeper Levels of Participation in Nature-Based Solutions in Urban Landscapes - A Literature Review of Real-World Cases. Landscape Urban Plann. 210, 104065. doi:10.1016/j.landurbplan.2021.104065

Rambonilaza, T., Joalland, O., and Brahic, E. (2016). Landowner's Perception of Flood Risk and Preventive Actions in Estuarine Environment: An Empirical Investigation. J. Environ. Manag. 180, 272-279. doi:10.1016/ j.jenvman.2016.05.037

Raymond, C. M., Frantzeskaki, N., Kabisch, N., Berry, P., Breil, M., Nita, M. R., et al. (2017). A Framework for Assessing and Implementing the Co-benefits of Nature-Based Solutions in Urban Areas. Environ. Sci. Pol. 77, 15-24. doi:10.1016/j.envsci.2017.07.008

Reed, M. S. (2008). Stakeholder Participation for Environmental Management: A Literature Review. Biol. Conservation. 141 (10), 2417-2431. doi:10.1016/ j.biocon.2008.07.014

Reguero, B. G., Beck, M. W., Bresch, D. N., Calil, J., and Meliane, I. (2018). Comparing the Cost Effectiveness of Nature-Based and Coastal Adaptation: A Case Study from the Gulf Coast of the United States. PloS one 13 (4), e0192132. doi:10.1371/journal.pone.0192132

Reid, W. V., Chen, D., Goldfarb, L., Hackmann, H., Lee, Y. T., Mokhele, K., et al. (2010). Earth System Science for Global Sustainability: Grand Challenges. Science 330 (6006), 916-917. doi:10.1126/science.1196263

Roca, E., and Villares, M. (2012). Public Perceptions of Managed Realignment Strategies: The Case Study of the Ebro Delta in the Mediterranean basin. Ocean Coastal Management. 60, 38-47. doi:10.1016/j.ocecoaman.2012.01.002

Rogers, R. W. (1975). A Protection Motivation Theory of Fear Appeals and Attitude Changel. J. Psychol. 91 (1), 93-114. doi:10.1080/ 00223980.1975.9915803

Ruangpan, L., Vojinovic, Z., Plavšić, J., Doong, D.-J., Bahlmann, T., Alves, A., et al. (2020). Incorporating Stakeholders' Preferences into a Multi-Criteria Framework for Planning Large-Scale Nature-Based Solutions. Ambio. 50, 1514-1531. doi:10.1007/s13280-020-01419-4

Rundmo, T. (2002). Associations between Affect and Risk Perception. J. Risk Res. 5 (2), 119-135. doi:10.1080/136698702753499597

Schaich, H. (2009). Local Residents' Perceptions of Floodplain Restoration Measures in Luxembourg's Syr Valley. Landscape Urban Plann. 93 (1), 20-30. doi:10.1016/j.landurbplan.2009.05.020

Schernewski, G., Schumacher, J., Weisner, E., and Donges, L. (2018). A Combined Coastal protection, Realignment and Wetland Restoration Scheme in the Southern Baltic: Planning Process, Public Information and Participation. J. Coast Conserv. 22 (3), 533-547. doi:10.1007/s11852-017-0542-4

Schmidt, L., Gomes, C., Guerreiro, S., and O'Riordan, T. (2014). Are We All on the Same Boat? the Challenge of Adaptation Facing Portuguese Coastal Communities: Risk Perception, Trust-Building and Genuine Participation. Land Use Policy. 38, 355-365. doi:10.1016/j.landusepol.2013.11.008

Scholte, S. S. K., Todorova, M., van Teeffelen, A. J. A., Verburg, P. H., and Verburg, P. H. (2016). Public Support for Wetland Restoration: What is the Link with Ecosystem Service Values? Wetlands. 36 (3), 467-481. doi:10.1007/s13157-016-0755-6

Seddon, N., Chausson, A., Berry, P., Girardin, C. A. J., Smith, A., and Turner, B. (2020). Understanding the Value and Limits of Nature-Based Solutions to Climate Change and Other Global Challenges. Phil. Trans. R. Soc. B. 375 (1794), 20190120. doi:10.1098/rstb.2019.0120

Shah, M. A. R., Renaud, F. G., Anderson, C. C., Wild, A., Domeneghetti, A., Polderman, A., et al. (2020). A Review of Hydro-Meteorological hazard, Vulnerability, and Risk Assessment Frameworks and Indicators in the
Context of Nature-Based Solutions. Int. J. Disaster Risk Reduction. 50, 101728. doi:10.1016/j.ijdrr.2020.101728

Sheeran, P. (2002). Intention-Behavior Relations: A Conceptual and Empirical Review. Eur. Rev. Soc. Psychol. 12 (1), 1-36. doi:10.1080/14792772143000003

Siegrist, M., and Árvai, J. (2020). Risk Perception: Reflections on 40 Years of Research. Risk Anal. 40 (S1), 2191-2206. doi:10.1111/risa.13599

Siegrist, M., Gutscher, H., and Earle, T. C. (2005). Perception of Risk: the Influence of General Trust, and General Confidence. J. Risk Res. 8 (2), 145-156. doi:10.1080/1366987032000105315

Siegrist, M. (2019). Trust and Risk Perception: A Critical Review of the Literature. Risk Anal. 41, 480-490. doi:10.1111/risa.13325

Simon, F., AdamKendall-Taylor, N., and Lindland, E. (2013). Using Values to Build Public Understanding and Support for Environmental Health Work. A Frameworks Research Report: May 2013. With assistance of Tracy Kolian and Amanda Raziano of the American Public Health Association.

Sjoberg, L. (1999). Consequences of Perceived Risk: Demand for Mitigation. J. Risk Res. 2 (2), 129-149. doi:10.1080/136698799376899

Sjoberg, L. (2000). Consequences Matter, 'Risk' Is Marginal. J. Risk Res. 3 (3), 287-295. doi:10.1080/13669870050043189

Slovic, P., Fischoff, B., and Lichtenstein, S. (1985). "Characterizing Perceived Risk," Perilous progress: Managing the hazards of technology. Editors R. W. Kates, C. Hohenemser, and J. X. Kasperson (Boulder, CO: Westview), 91-125.

Slovic, P., Finucane, M. L., Peters, E., and MacGregor, D. G. (2004). Risk as Analysis and Risk as Feelings: Some Thoughts about Affect, Reason, Risk, and Rationality. Risk Anal. 24 (2), 311-322. doi:10.1111/j.0272-4332.2004.00433.x

Slovic, P. (1999). Trust, Emotion, Sex, Politics, and Science: Surveying the Risk-Assessment Battlefield. Risk Anal. 19 (4), 689-701. doi:10.1111/j.1539-6924.1999.tb00439.x

Steg, L., and Vlek, C. (2009). Encouraging Pro-environmental Behaviour: An Integrative Review and Research Agenda. J. Environ. Psychol. 29 (3), 309-317. doi:10.1016/j.jenvp.2008.10.004

Stern, P. C. (2000). New Environmental Theories: Toward a Coherent Theory of Environmentally Significant Behavior. J. Soc. Isssues. 56 (3), 407-424. doi:10.1111/0022-4537.00175

Terpstra, T. (2011). Emotions, Trust, and Perceived Risk: Affective and Cognitive Routes to Flood Preparedness Behavior. Risk Anal. : official Publ. Soc. Risk Anal. 31 (10), 1658-1675. doi:10.1111/j.1539-6924.2011.01616.x

Thompson, B. (1995). Stepwise Regression and Stepwise Discriminant Analysis Need Not Apply Here: A Guidelines Editorial. Educ. Psychol. Meas. 55 (4), 525-534. doi:10.1177/0013164495055004001

Triyanti, A., Bavinck, M., Gupta, J., and Marfai, M. A. (2017). Social Capital, Interactive Governance and Coastal protection: The Effectiveness of Mangrove EcosystemBased Strategies in Promoting Inclusive Development in Demak, Indonesia. Ocean Coastal Management. 150, 3-11. doi:10.1016/j.ocecoaman.2017.10.017

Turner, B. L., II, Kasperson, R. E., Matson, P. A., McCarthy, J. J., Corell, R. W., Christensen, L., Eckley, N., et al. (2003). A Framework for Vulnerability Analysis in Sustainability Science. Proc Natl Acad Sci U S A. 100 (14), 8074-8079. doi:10.1073/pnas.1231335100

United Nations Office for Disaster Risk Reduction (2015). "Sendai Framework for Disaster Risk Reduction 2015 - 2030. In United Nations Office for Disaster Risk Reduction," in UN World Conference on Disaster Risk Reduction (Sendai, Japan: United Nations Office for Disaster Risk Reduction). Available online at http:// www.wcdrr.org/uploads/Sendai_Framework_for_Disaster_Risk_Reduction_20152030.pdf (Accessed January 24, 2021).

United Nations (2015). Transforming Our World: The 2030 Agenda for Sustainable Development. New York, NY: United Nations.

van der Vegt, R. G. (2018). A Literature Review on the Relationship between Risk Governance and Public Engagement in Relation to Complex Environmental Issues. J. Risk Res. 21 (11), 1-18. doi:10.1080/13669877.2017.1351466

Verbrugge, L. N. H., Ganzevoort, W., Fliervoet, J. M., Panten, K., van den Born, R. J. G., and Riyan, J. G. (2017). Implementing Participatory Monitoring in River Management: The Role of Stakeholders' Perspectives and Incentives. J. Environ. Manag. 195 (Pt 1), 62-69. doi:10.1016/j.jenvman.2016.11.035 
Viklund, M. J. (2003). Trust and Risk Perception in Western Europe: A CrossNational Study. Risk Anal. 23 (4), 727-738. doi:10.1111/1539-6924.00351

Wamsler, C., Alkan-Olsson, J., Björn, H., Falck, H., Hanson, H., Oskarsson, T., et al. (2019). Beyond Participation: when Citizen Engagement Leads to Undesirable Outcomes for Nature-Based Solutions and Climate Change Adaptation. Climatic Change. 158 (2), 235-254. doi:10.1007/s10584-01902557-9

Williams, L., Macnaghten, P., Davies, R., and Curtis, S. (2017). Framing 'fracking': Exploring Public Perceptions of Hydraulic Fracturing in the United Kingdom. Public Underst Sci. 26 (1), 89-104. doi:10.1177/0963662515595159

Wilson VanVoorhis, C. R., and Morgan, B. L. (2007). Understanding Power and Rules of Thumb for Determining Sample Sizes. Tutorials Quantitative Methods Psychol. 3 (2), 43-50. doi:10.20982/TQMP.03.2.P043

World Bank (2015). World Development Report 2015: Mind, Society, and Behavior. Washington, DC: World Bank Group.

Zingraff-Hamed, A., Hüesker, F., Lupp, G., Begg, C., Huang, J., Oen, A., et al. (2020). Stakeholder Mapping to Co-create Nature-Based Solutions: Who Is on Board? Sustainability. 12 (20), 8625. doi:10.3390/su12208625
Conflict of Interest: The authors declare that the research was conducted in the absence of any commercial or financial relationships that could be construed as a potential conflict of interest.

Publisher's Note: All claims expressed in this article are solely those of the authors and do not necessarily represent those of their affiliated organizations, or those of the publisher, the editors and the reviewers. Any product that may be evaluated in this article, or claim that may be made by its manufacturer, is not guaranteed or endorsed by the publisher.

Copyright (C) 2021 Anderson, Renaud, Hanscomb, Munro, Gonzalez-Ollauri, Thomson, Pouta, Soini, Loupis, Panga and Stefanopoulou. This is an openaccess article distributed under the terms of the Creative Commons Attribution License (CC BY). The use, distribution or reproduction in other forums is permitted, provided the original author(s) and the copyright owner(s) are credited and that the original publication in this journal is cited, in accordance with accepted academic practice. No use, distribution or reproduction is permitted which does not comply with these terms. 